\title{
Microdistribution and quantification of the boron neutron capture therapy drug BPA in primary cell cultures of human glioblastoma tumour by NanoSIMS
} DOI:

10.1039/C9AN01336A

\section{Document Version}

Accepted author manuscript

Link to publication record in Manchester Research Explorer

Citation for published version (APA):

Aldossari, S., Mcmahon, G., Lockyer, N., \& Moore, K. (2019). Microdistribution and quantification of the boron neutron capture therapy drug BPA in primary cell cultures of human glioblastoma tumour by NanoSIMS. The Analyst. https://doi.org/10.1039/C9AN01336A

\section{Published in:}

The Analyst

\section{Citing this paper}

Please note that where the full-text provided on Manchester Research Explorer is the Author Accepted Manuscript or Proof version this may differ from the final Published version. If citing, it is advised that you check and use the publisher's definitive version.

\section{General rights}

Copyright and moral rights for the publications made accessible in the Research Explorer are retained by the authors and/or other copyright owners and it is a condition of accessing publications that users recognise and abide by the legal requirements associated with these rights.

\section{Takedown policy}

If you believe that this document breaches copyright please refer to the University of Manchester's Takedown Procedures [http://man.ac.uk/04Y6Bo] or contact uml.scholarlycommunications@manchester.ac.uk providing relevant details, so we can investigate your claim.

\section{OPEN ACCESS}




\section{Analyst}

\section{Microdistribution and quantification of the boron neutron capture therapy drug BPA in primary cell cultures of human glioblastoma tumour by NanoSIMS}

\begin{tabular}{|r|l|}
\hline Journal: & Analyst \\
\hline Manuscript ID & AN-ART-07-2019-001336.R1 \\
\hline Article Type: & Paper \\
\hline Author: & 28-Aug-2019 \\
\hline Complete List of Authors: & $\begin{array}{l}\text { Aldossari, Samar; The University of Manchester, Department of } \\
\text { Chemistry } \\
\text { McMahon, Greg; The University of Manchester, Department of Materials; } \\
\text { National Physical Laboratory } \\
\text { Lockyer, Nicholas; The University of Manchester, Department of } \\
\text { Chemistry } \\
\text { Moore, Katie; The University of Manchester, Department of Materials }\end{array}$ \\
\hline
\end{tabular}

\section{SCHOLARONE \\ Manuscripts}




\title{
Microdistribution and quantification of the boron neutron capture therapy drug BPA in primary cell cultures of human glioblastoma tumour by NanoSIMS
}

\author{
Samar Aldossari ${ }^{1,2}$, Greg McMahon 2,3,4, Nicholas P. Lockyer ${ }^{1,2}$, Katie L. Moore 2,3 \\ ${ }^{1}$ Department of Chemistry, University of Manchester, Oxford Rd, Manchester M13 9PL. \\ 2Photon Science Institute, University of Manchester, Oxford Rd, Manchester M13 9PL. \\ ${ }^{3}$ Department of Materials, University of Manchester, Oxford Rd, Manchester M13 9PL. \\ ${ }^{4}$ Current address: National Physical Laboratory, National Centre of Excellence in Mass \\ Spectrometry Imaging, Hampton Rd., Teddington, TW11 OLW
}

Nick.Lockyer@manchester.ac.uk

\begin{abstract}
The ability of secondary ion mass spectrometry (SIMS) to provide high sensitivity imaging of elements and small-medium mass molecules in biological tissues and cells, makes it a very powerful tool for drug distribution studies. Here we report on the application of a highresolution dynamic SIMS instrument for the quantification and localisation of therapeutic levels of the BNCT agent L-para-(dihydroxyboryl)-phenylalanine (BPA) in primary cell cultures from human patients exhibiting glioblastoma multiform tumours. Boron uptake and distribution was determined quantitatively as a function of cell-sampling location and different treatment regimes. Importantly, BPA was found to accumulate in cancer cells
\end{abstract}


invading the 'brain around tumour' tissue in addition to the main tumour site. Pretreatment of samples with L-tyrosine was found not to increase the uptake of BPA, nor change the intracellular drug distribution. In cultured cells from the tumour core and brain around tumour, with and without L-tyrosine pre-treatment, normalised boron-related signals were higher from cell nuclei than from cytoplasm. An efflux treatment was found to reduce BPA levels, but at a rate slower than the original uptake, and did not affect the intracellular drug distribution. To the best of our knowledge, these data represent the first published study of BPA uptake and L-amino acid pre-treatment in cultured primary human cells using dynamic SIMS, and the most detailed, subcellular distribution study of a BNCT agent in any cellular system.

\section{Keywords}

BNCT, boron neutral capture therapy, glioblastoma multiform, 10B-BPA, SIMS, drug distribution

\section{Introduction}

Glioblastoma multiform tumour (GBM) is the most frequent type of primary malignant brain tumour and is universally fatal. ${ }^{1}$ High grade GBM are amongst the most difficult human malignancies to treat, occurring deep inside the brain, proliferating quickly, infiltrating surrounding tissues and leading to recurrence. ${ }^{2,3}$ Median survival is $<15$ months after diagnosis even with optimal contemporary therapy of surgery, radiotherapy, and chemotherapy. ${ }^{4}$ One of the most promising experimental treatments for highly aggressive 


\begin{abstract}
GBM and other intractable tumours such as head and neck tumours and cutaneous melanomas is boron neutron capture therapy $(\mathrm{BNCT}) .{ }^{5,6}$
\end{abstract}

Briefly, BNCT is a form of bimodal radiotherapy that depends on the preferential accumulation of ${ }^{10} \mathrm{~B}$ containing drugs, in the tumour core and the tumour cells infiltrating surrounding normal tissue. Prior to radiotherapy, BNCT patients are administered with an agent to deliver ${ }^{10} \mathrm{~B}$ specifically to target regions. Following boron uptake, tumour sites are then exposed to thermal neutrons $(0.025 \mathrm{eV})$ or epithermal neutrons $(10 \mathrm{keV}) .{ }^{7}$ The ${ }^{10} \mathrm{~B}$ captures the thermal neutrons to undergo fission reaction and produce linear energy transfer alpha particles $\left({ }^{4} \mathrm{He}\right)$, and recoiling ${ }^{7} \mathrm{Li}$ nuclei. ${ }^{7,8}$ These fission products can penetrate the tissue with a high linear radiant energy transfer at short distances $(9 \mu \mathrm{m}$ and $5 \mu \mathrm{m}$ respectively), killing the cells in the close vicinity ${ }^{7,9-11}$ whilst the cells that have not taken up ${ }^{10} \mathrm{~B}$ remain unaffected by the radiation dose.

Despite much research into alternative boron-containing drugs, L-para-(dihydroxyboryl)phenylalanine (BPA) and sodium borocaptate (BSH) are the only two boron delivery agents in clinical BNCT use. In particular, the amino acid analogue BPA is effective in delivering boron in melanomas ${ }^{12}$ and gliomas ${ }^{13}$ - highly malignant tumours contain proliferating cells which show extensive amino acid uptake. The improved efficacy of the technique currently relies on more favourable dosing and delivery paradigms for these compounds. ${ }^{7}$ Important parameters include the concentration, microdistribution and stability of the boron agent in the tumour cells and the rate of clearance from non-tumour cells and tissues. In attempts to improve the delivery of BPA to tumour tissue and tumour cells infiltrating the normal brain, amino acids such as L-tyrosine have been dosed before starting drug treatment. ${ }^{8}$ BPA is a molecule analogous in structure to tyrosine which is actively transported to cells using the 
same mechanism, via the membrane-situated L-amino acid transporter-1 (LAT-1) . ${ }^{14-18}$ LAT1 has been shown to be over-expressed in malignant tumours ${ }^{19-21}$ and contributes to the specific uptake of BPA in cancer cells. ${ }^{22}$ Pre-accumulation of L-tyrosine can lead to the stimulation of exchange and transport between L-tyrosine intracellularly and L-BPA extracellularly. However, a review of the relevant literature shows that L-amino acid pretreatment is not universally successful in increasing the uptake of L-BPA. ${ }^{23-25}$ Papaspyrou et al. showed that pre-treatment of mouse melanoma cells with L-tyrosine stimulated BPA uptake $^{26}$ and Wittig et al. found that BPA uptake increased two-fold in rat 9L gliosarcoma cells when preloaded with L-tyrosine before L-BPA administration, comparing with cells that were not preloaded with L-tyrosine. ${ }^{15}$ Wingelhofer et al. also found that pre-treatment with L-tyrosine enhanced the ${ }^{18} \mathrm{~F}-\mathrm{FBPA}$ (2-fluoro-4-borono-L-phenylalanine) intracellular concentration in three different types of human and mouse tumour cell lines. ${ }^{27}$ Capuani et al. presented two studies showing the possibility of enhancing BPA uptake by using another L- amino acid (L-DOPA) with C6-glioma cells in vitro and in vivo. ${ }^{28,29}$ In contrast, Detta and Cruickshank presented a study on human brain tumour and brain around tumour harvested from patients with glioblastoma, which showed that pre-loading with L-tyrosine did not show any improvement in BPA uptake in these tissues. ${ }^{30}$ Similarly, Grunewald et al. showed that neither L-tyrosine nor L-DOPA affected the BPA uptake in different organelles of mice preinjected with a human hepatocellular carcinoma cell line, and this was attributed either to LAT-1 expression varying from one patient to another or the effect of L-tyrosine varying from one tumour to another. ${ }^{31}$ Yang et al. concluded that the effect of pre-treatment with Lamino acid as a stimulator of BPA uptake varies according to the histologic tumour type and the anatomic location of the tumour. ${ }^{32}$ 
The therapeutic benefit of BNCT treatment requires sufficient ${ }^{10} \mathrm{~B}$ concentration $(\sim 15-30$ $\mu \mathrm{g} / \mathrm{g}$ or $\sim 10^{9}$ atoms/cell) in tumour cells, ${ }^{33,34}$ specifically the cellular nuclei, due to the short penetration distance of the fission products. Bulk analytical methods can provide quantitative information of the level of boron in blood and tissue to help determine if the required levels of ${ }^{10} \mathrm{~B}$ have been achieved. ${ }^{35,36}$ For example, Detta and Cruickshank measured clinically relevant bulk BPA concentrations using inductively coupled plasma mass spectrometry (ICP-MS). ${ }^{30}$ Basilico et al. reported the quantification of BPA in blood and urine, using flow-injection electrospray tandem mass spectrometry (FI/ESI-MS/MS) with high sensitivity to measure concentrations down to $10 \mu \mathrm{g} / \mathrm{g} \cdot{ }^{37}$ Wittig et al. measured BPA transport through cell membranes in vitro using direct current plasma atomic emission spectroscopy (DCP-AES). ${ }^{15}$ While bulk techniques are vital to BNCT research, they are not able to determine the amount of ${ }^{10} \mathrm{~B}$ in the cells themselves (as opposed to blood within the tumour, or the bulk biopsy) nor determine if there is enhanced accumulation of ${ }^{10} \mathrm{~B}$ within the nucleus. A calculated $\sim 10$-fold less ${ }^{10} \mathrm{~B}$ is needed to produce cell death if it is located intracellularly rather than extracellularly due to the lethal range of the ${ }^{10} \mathrm{~B}(\mathrm{n}, \alpha)^{7} \mathrm{Li}$ reaction. ${ }^{38,39}$ The radiobiological effect and the efficacy of BNCT treatment is therefore critically linked to the ${ }^{10} \mathrm{~B}$ distribution on a sub-cellular scale. Additionally, to minimize damage to healthy tissues the ${ }^{10} \mathrm{~B}$ concentration in tumour cells should be three or more times higher than that of normal cells. ${ }^{8,10,40,41}$ In order to limit recurrence rates, crucial targets for BNCT are the neoplastic cells that infiltrate the normal tissues around the tumour core, so-called brain around tumour (BAT). ${ }^{42}$ Previous studies have reported differential ${ }^{10} \mathrm{~B}$ uptake in these cells, compared to the main tumour mass, depending on the duration of drug dosing. ${ }^{43-45}$ It is therefore important to study the pharmacokinetics of ${ }^{10} \mathrm{~B}$ uptake and distribution as this may influence the BNCT treatment regime. 
The optimum ${ }^{10} \mathrm{~B}$ delivery method and dosing paradigm for $\mathrm{BNCT}$ have yet to be determined. Cellular and sub-cellular level chemical imaging is necessary to support dosimetry studies and clinical efficacy in $\mathrm{BNCT}^{35}$ and more generally novel drug delivery research. Clinically approved imaging modalities including magnetic resonance $\left({ }^{1} \mathrm{H}\right.$ in BPA) and positron emission tomography $\left({ }^{18} \mathrm{~F}-\mathrm{FBPA}\right)$ lack the spatial resolution to determine invivo BPA distributions on a cellular scale..$^{22,46} \mathrm{It}$ is essential to develop and assess alternative methods capable of determining the localization and distribution of ${ }^{10} \mathrm{~B}$ of $\mathrm{BPA}$ at the cellular level in tumour cells in order to enhance the success of BNCT treatment. Secondary ion mass spectrometry (SIMS) imaging is one such technique.

A number of SIMS studies of the uptake and distribution of BNCT agents have previously been reported in the literature, most notably by Chandra et al (see for example ${ }^{43}$ ). SIMS studies have mostly focused on the application of the ion microscope technique using a high-current, defocused $\mathrm{O}_{2}{ }^{+}$primary beam and detecting positive secondary ions using a position sensitive detector. In this technique spatial resolution is limited to approximately 1 $\mu \mathrm{m}$ by the ion optics of the instrument in a manner analogous to traditional light microscopy. Microprobe methods using focused primary ion beams have also been applied, and combined with laser post-ionisation techniques to increase sensitivity and quantification levels. ${ }^{47}$ In contrast to the work reported here, previous studies have been conducted on established glioma model cell lines such as T98G, animal tissues or glioblastoma xenografts grown in nude mice. Primary glioma tissues show tumour heterogeneity which can influence ${ }^{10} \mathrm{~B}$ uptake in cell subpopulations. ${ }^{42,48}$ As discussed above, the effect of tyrosine pre-loading was found to be sample-type dependent. It is therefore important to measure the outcome of BNCT agent exposure and dosing regimes on primary human glioma cells and ultimately human tumour biopsies to best inform clinical 
practice. The aims of this study were to determine the sub-cellular distribution and semiquantitative uptake and efflux of BPA for the first time in primary human glioblastoma cells. The study includes samples pre-loaded with L-tyrosine to determine for the first time the effect of this process on the intracellular BPA distribution in primary glioblastoma cell treated in vitro. The results include the most detailed BNCT drug distribution study to-date and further demonstrate the capability of the dynamic SIMS technique to support clinical research and personalized therapy.

\section{Experimental}

\subsection{Sample preparation}

Samples were provided from the Molecular Neuro-oncology Laboratory in the Queen Elizabeth Neuroscience Centre, The University of Birmingham, UK, in accordance with local ethical guidelines. Biopsies were obtained with written informed consent from a patient with a presumptive diagnosis of high-grade glioma undergoing routine craniotomy as part of the diagnostic process prior to the definitive treatment. Definitive histological diagnosis was made on hematoxylin and eosin (H\&E) stained routine paraffin sections. The cell cultures for SIMS analysis were prepared to ensure the removal of any contamination or other cell types such as blood cells, fibroblast cells, stromal cells and glial cells. Samples were prepared in six stages as described below.

Tissue harvesting: From the operating theatre, fresh unfixed brain tumour (GBM) and brain-around-tumour (BAT) biopsies ( $1 \mathrm{~cm}^{3}$ of tumour tissue and a lesser amount of BAT tissue) were collected and placed promptly in ice-cold medium dedicated for tissue. The collection medium contains: $100 \mu \mathrm{g} / \mathrm{ml}$ gentamicin, $200 \mu \mathrm{g} / \mathrm{ml}$ streptomycin, Ham's F12 medium complemented with $20 \mathrm{mM}$ HEPES buffer, $2.5 \mu \mathrm{g} / \mathrm{ml}$ Fungizone and $200 \mathrm{U} / \mathrm{ml}$ 
penicillin (all from ThermoFisher, UK). The remaining tissue parts were kept routinely in formal-saline for use in other diagnostic and histopathological studies.

Tissue dispersion: Within an hour of harvesting, the remaining blood in tissue was washed three times with ice-cold Hank's Balanced Salt Solution (HBSS), and any blood clots were peeled off. The tissue was divided into slices of about $1 \mathrm{~mm}^{3}$ size using crossed scalpels, and then washed again with ice-cold HBSS. Slices were re-suspended in $30 \mathrm{~mL}$ of HBSS and exposed to digestion at $37{ }^{\circ} \mathrm{C}$ and $4{ }^{\circ} \mathrm{C}$ respectively for $30 \mathrm{~min}$ in the following enzymes mixture: $0.25 \mathrm{mg} / \mathrm{ml}$ collagenase (Invitrogen, Life Technologies), $0.4 \mathrm{mg} / \mathrm{ml}$ DNase, and 0.5 $\mathrm{mg} / \mathrm{ml}$ pronase (both from Sigma Aldrich, UK). The slices were filtered from the enzyme mixture to remove undigested materials using nylon mesh (100 $\mu \mathrm{m}$ pore) and then were placed upon $2 \times 12 \mathrm{ml}$ of Ficoll-paque intensity gradient media (Amersham Pharmacia, UK). Centrifugation was performed for $30 \mathrm{~min}$ at $400 \mathrm{~g}$ at room temperature resulting in dispersion and separation of tumour cells on the surface, while the red blood cells were sedimented at the bottom of tube. Finally, HBSS was used to wash the cells once and then they were re-suspended in the same solution for viability test. ${ }^{49}$ This method of dispersing tissue was modified from the original one by Farr-Jones et al. . ${ }^{50}$

Viability: Dispersed cells showed high degrees of viability, this was verified using the Trypan blue exclusion method. ${ }^{51}$

Cell plating: The following medium was used for seeding tissue biopsies and forming cultures: $2 \times 10^{5} / \mathrm{cm}^{2}$ in 1:1 of DMEM/F12 (Invitrogen, Life Technologies) complemented with $10 \%$ pooled human plasma (Patricell Ltd, UK), $2 \mathrm{mM}$ of L-glutamine, $0.05 \mathrm{mM}$ of nonessential amino acids, $100 \mu \mathrm{M}$ of sodium pyruvate (all from Invitrogen, Life Technologies), $2.5 \mu \mathrm{g} / \mathrm{ml}$ of Fungizone, $100 \mathrm{U} / \mathrm{ml}$ of penicillin and $100 \mu \mathrm{g} / \mathrm{ml}$ of streptomycin onto $5 \times 7$ 
$\mathrm{mm}^{2}$ sterile silicon wafers placed in 12-well plates in duplicates, then incubated overnight with $99 \%$ humidity and $5 \% \mathrm{CO}_{2}$ at $37{ }^{\circ} \mathrm{C}$. The next day, the medium was renewed after the unattached cells were removed by the aspiration method. Cells were left to grow for 7 days and then transferred to the treatment step. ${ }^{49}$

Cell treatment: Clinical grade ${ }^{10} \mathrm{~B}-\mathrm{BPA}$ was gifted by Cancer Research UK and formulated at $100 \mathrm{mg} / \mathrm{mL}$ in $110 \mathrm{mg} / \mathrm{mL}$ mannitol. For cell treatment the BPA was added at $110 \mu \mathrm{g} / \mathrm{mL}$ boron equivalent at $37{ }^{\circ} \mathrm{C}$, a concentration that has been successfully tolerated in human and animal trials. ${ }^{19,52}$ There were 4 different biopsies: 2 of GBM tumour $(T)$ and 2 of BAT tissue (B) and 4 treatment groups:

1. Control (no treatment)

2. $10 \mathrm{mM}$ BPA-mannitol for $4 \mathrm{~h}$

3. $10 \mathrm{mM}$ tyrosine-mannitol for $4 \mathrm{~h}$ followed by a wash and then $4 \mathrm{~h}$ incubation with 10 mM BPA-mannitol

4. $4 \mathrm{~h}$ BPA-mannitol (10 $\mathrm{mM})$ followed by $4 \mathrm{~h}$ efflux.

After treatment, the cells on silicon wafers were washed with ice-cold physiological pH saline and were immediately flash-frozen in isopentane/liquid nitrogen and stored at $-80^{\circ} \mathrm{C}$.

Preparing for SIMS analysis: Samples were transferred to The University of Manchester on solid carbon dioxide at $-78{ }^{\circ} \mathrm{C}$ and then stored at $-80{ }^{\circ} \mathrm{C}$. Prior to analysis with SIMS they were mounted on a pre-cooled copper stub under $\mathrm{N}_{2}$ gas flow and left in a vacuum chamber overnight and under a pressure of $1 \times 10^{-8}$ mbar. After 24 hours, the freeze-dried samples were ready for SIMS analysis. 


\subsection{NanoSIMS analysis and data processing}

SIMS analysis of samples was performed using a NanoSIMS 50L (Cameca Ltd, France) instrument at the University of Manchester. The NanoSIMS instrument has been described in detail elsewhere. ${ }^{53}$ The instrument was tuned to detect the following negative secondary ions ${ }^{10} \mathrm{~B},{ }^{12} \mathrm{C},{ }^{10} \mathrm{~B}^{12} \mathrm{C},{ }^{12} \mathrm{C}^{14} \mathrm{~N},{ }^{29} \mathrm{Si},{ }^{31} \mathrm{P}$ and ${ }^{32} \mathrm{~S}$ simultaneously as well as the ion induced secondary electrons. The positions of the detectors were calibrated using bulk standards suitable for each ion to avoid any mass interferences. Cells were selected using a chargecoupled device (CCD) camera in the NanoSIMS instrument. $\mathrm{A} \mathrm{CS}^{+}$primary ion beam with a $16 \mathrm{keV}$ impact energy was used for analysis. Prior to imaging, each selected area was implanted with a dose of $1.9 \times 10^{16} \mathrm{Cs}^{+}$ions $/ \mathrm{cm}^{2}$ using a defocused $\mathrm{Cs}^{+}$beam (D1=0) by rastering over an area of $100 \times 100 \mu \mathrm{m}^{2}$ field of view (FoV) in order to both increase and avoid large changes in secondary ion yields. In these samples it was not possible to reach steady state across the whole cell as the cytoplasm sputtered more quickly than the nucleus so this dose was chosen to maximise secondary ion signal without significant loss of cellular material prior to data acquisition. Ion images were then acquired by sequentially imaging the cells with a focused beam, adding a further dose of $1.4 \times 10^{16} \mathrm{Cs}^{+}$ions $/ \mathrm{cm}^{2}$ with $\mathrm{D} 1=2$ (300 $\mu \mathrm{m}$ aperture) with a beam current ranging from 1.9-5.3 pA. The entrance slit was set to ES $=3$ (width $=20 \mu \mathrm{m})$ and Aperture slit to AS $=2$ (width $=200 \mu \mathrm{m}$ ) to avoid mass interferences. During imaging the $\mathrm{Cs}^{+}$beam was rastered over a FoV between $35 \times 35 \mu \mathrm{m}^{2}$ and $60 \times 60 \mu \mathrm{m}^{2}$, depending on the single cell size, with $256 \times 256$ pixels and a dwell time of $2000 \mu \mathrm{s} /$ pixel. Both implantation and imaging doses were selected based on a depth profiling study of samples (Figure S1) that was conducted prior to commencement of the imaging study. 


\subsection{NanoSIMS data processing}

Image processing was performed using Fiji (an updated version of ImageJ 1.51a-Rasband, activated in 2015) with the multi-isotope imaging mass spectrometry (OpenMIMS v2.5) plugin. ${ }^{54}$ Image processing included drift correction, summing of image planes, selecting the sub-cellular regions of interest (ROIs), measuring ion intensities and statistical processing. ROIs were selected using the distribution of $\mathrm{CN}^{-}, \mathrm{P}^{-}$and $\mathrm{S}^{-}$signals to determine cell nuclei and cytoplasm. During the identification of the ROIs from the nucleus and cytoplasm, unknown features and surface topography which may affect the level of the resulting signals were avoided (for example cell B1 in Fig 3). In addition, the outer edges of the cells were not included in the ROIs due to lack of confidence in their identity. Absolute quantification is achieved by applying a relative sensitivity factor (RSF, $1 \times 10^{24} \mathrm{~cm}^{-3}$ ) measured for $\mathrm{B}^{-}$with respect to $\mathrm{C}^{-}$using a $14.5 \mathrm{keV} \mathrm{Cs}^{+}$ion beam in a PMMA standard ${ }^{55}$ and assuming the live cells are $85 \%$ water. It should be noted that the RSF was measured on a different instrument geometry, albeit with the same primary ion beam. Atomic density and electron affinity are the primary factors affecting RSF magnitude. ${ }^{56}$ Here we assume that secondary effects including incidence angle do not significantly affect quantification (through RSF) beyond our stated measurement uncertainty due to the similarity in $m / z$ of ${ }^{10} \mathrm{~B}$ and ${ }^{12} \mathrm{C}$. This assumption is supported by previous work that reports RSF values from NanoSIMS and other dynamic SIMS geometries (IMS-xF and IMS-1280 instruments) in close agreement, including Be/B measurements. ${ }^{57,58}$

\section{Results and Discussion}

\subsection{Cell Imaging}


Figure 1 shows optical micrographs of the samples and the selected cells from which the SIMS data presented in Figure 2 and Figure 3 was acquired. Where possible, cells were chosen that were isolated from other cells, large cells were avoided as they could not be imaged in their entirety in the NanoSIMS field of view, but otherwise were selected at random. The coverage of the silicon wafer was less than $70 \%$ to avoid any effects due to cell-cell interactions.

Selected ion images of primary GBM tumour cells (T) and BAT cells (B) exposed to different BPA treatment regimes are shown in Figure 2 and Figure 3 respectively. Ion-induced secondary electron (SE) images, together with the $\mathrm{C}^{-}$images, reveal the morphology of the cells and shows that the cells have been preserved after freeze-drying and that the cells are relatively flat which is necessary for reliable and semi-quantitative SIMS analysis. Both tumour and BAT cells have a similar morphology for all treatments.

The intracellular distributions of $\mathrm{CN}^{-}$and $\mathrm{P}^{-}$were used to differentiate the cell nucleus from the cytoplasm when selecting ROIs for sub-cellular quantification of BPA uptake. Both $\mathrm{CN}^{-}$ and $\mathrm{P}^{-}$are higher within the cell nucleus as expected considering the increased nucleic acid and phospholipid content. The ROIs identified as the nucleus for all treatments are outlined in green in Figure 2 and Figure 3. The periphery of the cells, showing high SE, $\mathrm{C}^{-}$and $\mathrm{P}^{-}$levels, are likely very thin layers of cellular material or residual culture medium adhered to the cell surface. These peripheral regions, showing enhanced sputter yields due to the effect of the underlying substrate and/or topography at the edge of the cell, were excluded from the subsequent data analysis. The remaining area of the cell, outlined in red in Figure 2 and Figure 3, was identified as the cytoplasm. The high spatial resolution of the NanoSIMS (measured 
at $400 \mathrm{~nm}$ on these samples) allows unambiguous identification of cellular features without the need for further complementary imaging such as optical microscopy. ${ }^{9}$

Boron was imaged in the NanoSIMS as both ${ }^{10} \mathrm{~B}^{-}$and ${ }^{10} \mathrm{~B}^{12} \mathrm{C}^{-}$. Both ions show almost identical distributions however the ${ }^{10} \mathrm{~B}^{12} \mathrm{C}^{-}$gave a higher secondary ion intensity indicating the relative stability of the ${ }^{10} \mathrm{~B}^{12} \mathrm{C}$ fragment and its higher ionisation probability compared to atomic ${ }^{10} \mathrm{~B}$. The control samples, $\mathrm{T} 1$ and $\mathrm{B} 1$, with no BPA treatment show very low, natural, levels of ${ }^{10} \mathrm{~B}^{-}$and ${ }^{10} \mathrm{~B}^{12} \mathrm{C}^{-}$signals across the whole cell with no increase in intensity in the nucleus or cytoplasm. As all images were acquired by adding the same imaging dose $\left(1.4 \times 10^{16} \mathrm{Cs}^{+}\right.$ions $\left./ \mathrm{cm}^{2}\right)$, the intensity scale for ${ }^{10} \mathrm{~B}^{-}$and ${ }^{10} \mathrm{~B}^{12} \mathrm{C}^{-}$signals in Figure 2 and Figure 3 has been set to be the same for all four treatments. The increase in boron signals after treatment with BPA is therefore clear. Excluding the periphery of the cells, the most noticeable increase in boron signal intensity after BPA treatment is within the nucleus for both the tumour and the BAT cells although there is a clear increase in the cytoplasm as well, which is more apparent in the BAT. As discussed above, nuclear enhancement of ${ }^{10} \mathrm{~B}$ is highly desirable for the success of BNCT and the NanoSIMS images demonstrate that BPA uptake is preferentially accumulated in the nucleus.

With the addition of tyrosine (samples T3 and B3) the intracellular distribution of ${ }^{10} \mathrm{~B}^{-}$and ${ }^{10} \mathrm{~B}^{12} \mathrm{C}^{-}$did not change. Boron signals remained most intense in the cell nuclei and elevated signals were still detected in the cytoplasm compared to the extracellular regions. From the raw intensity images alone it is not possible to determine if the relative amount of BPA has increased, hence we normalise ${ }^{10} \mathrm{~B}^{-}$and ${ }^{10} \mathrm{~B}^{12} \mathrm{C}^{-}$signals to $\mathrm{C}^{-}$for quantitative analysis. Finally, after the $4 \mathrm{~h}$ efflux process (samples $\mathrm{T} 4$ and $\mathrm{B} 4$ ) the ${ }^{10} \mathrm{~B}^{-}$and ${ }^{10} \mathrm{~B}^{12} \mathrm{C}^{-}$signal levels decreased 
but not to the levels observed in the control samples (T1 and B1) and localisation of these signals to the nucleus is still observed.

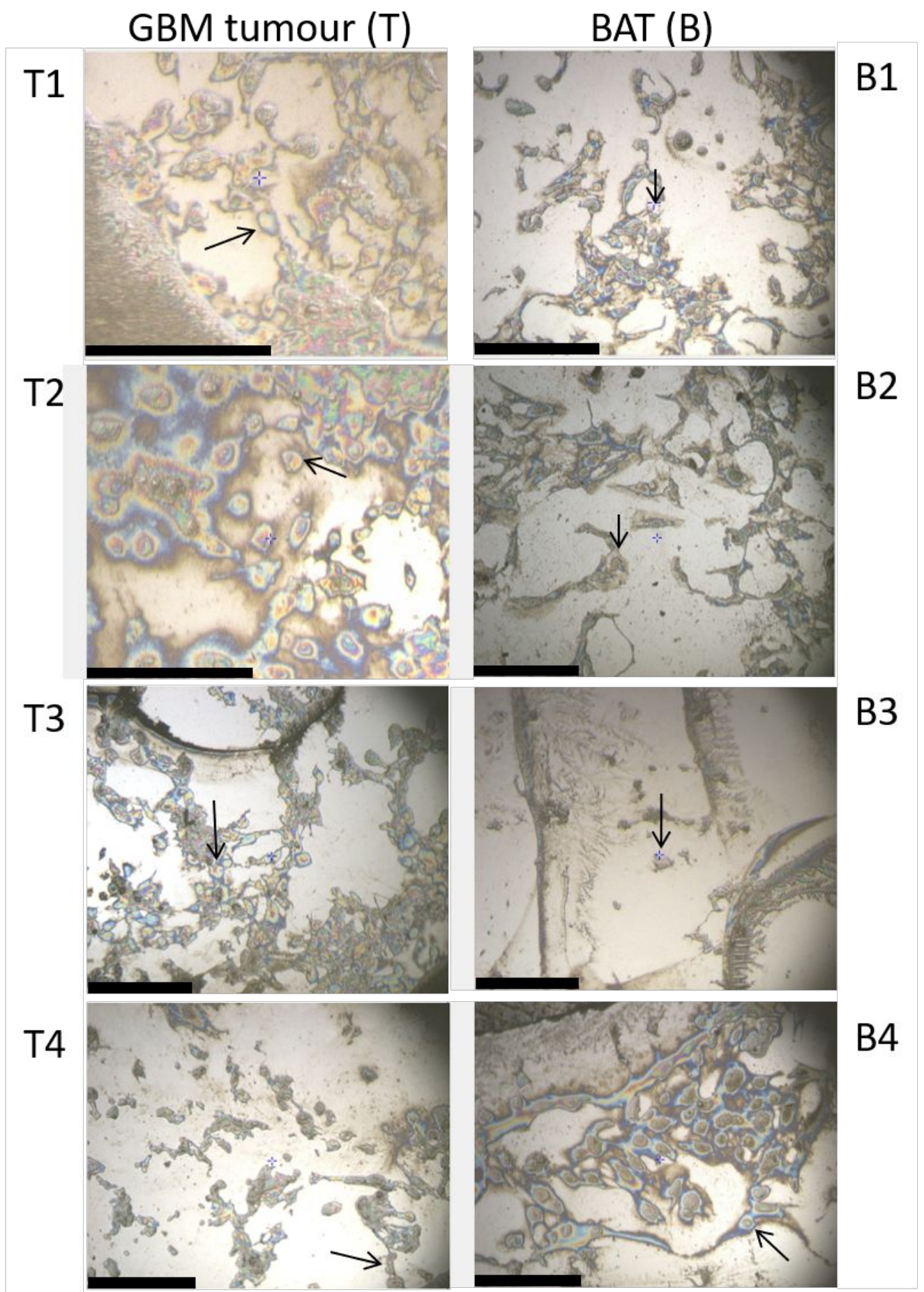

Figure 1: Optical micrographs of the cell samples on silicon wafers. Black arrows indicate the cells selected for SIMS imaging that are presented in Figure 2 and Figure 3. Scale bar $=200 \mu \mathrm{m}$. 


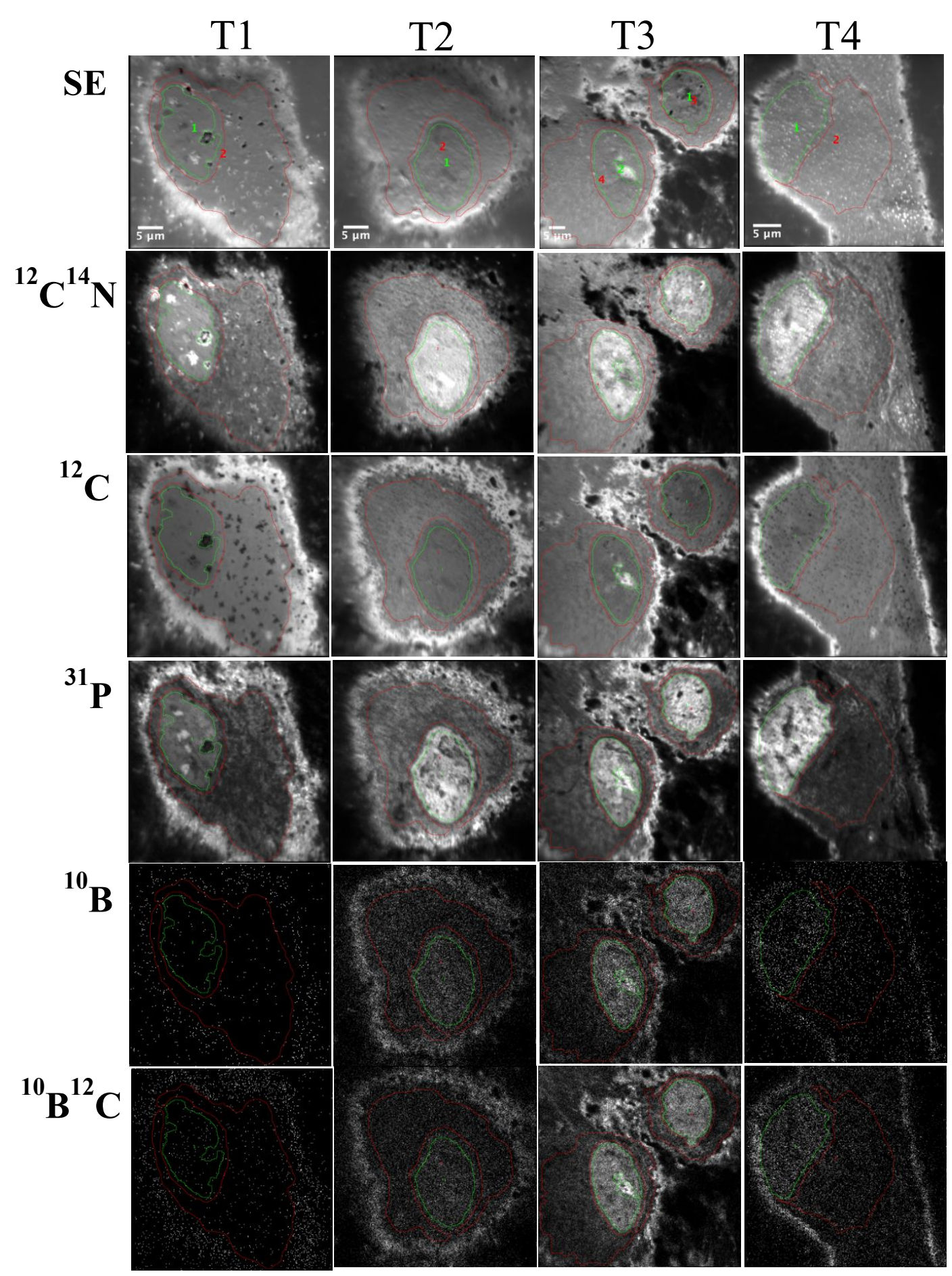

Figure 2: NanoSIMS images showing the four treatments for the tumour cells, 1-4. SE: secondary electron images showing the overall structure of the cell. NanoSIMS maps reveal the distribution of ${ }^{12} \mathrm{C}^{14} \mathrm{~N}^{-},{ }^{12} \mathrm{C}^{-},{ }^{31} \mathrm{P}^{-},{ }^{10} \mathrm{~B}^{-}$and ${ }^{10} \mathrm{~B}^{12} \mathrm{C}^{-}$within the cell, the nucleus is outlined with a green line and the cytoplasm outlined with a red line. 


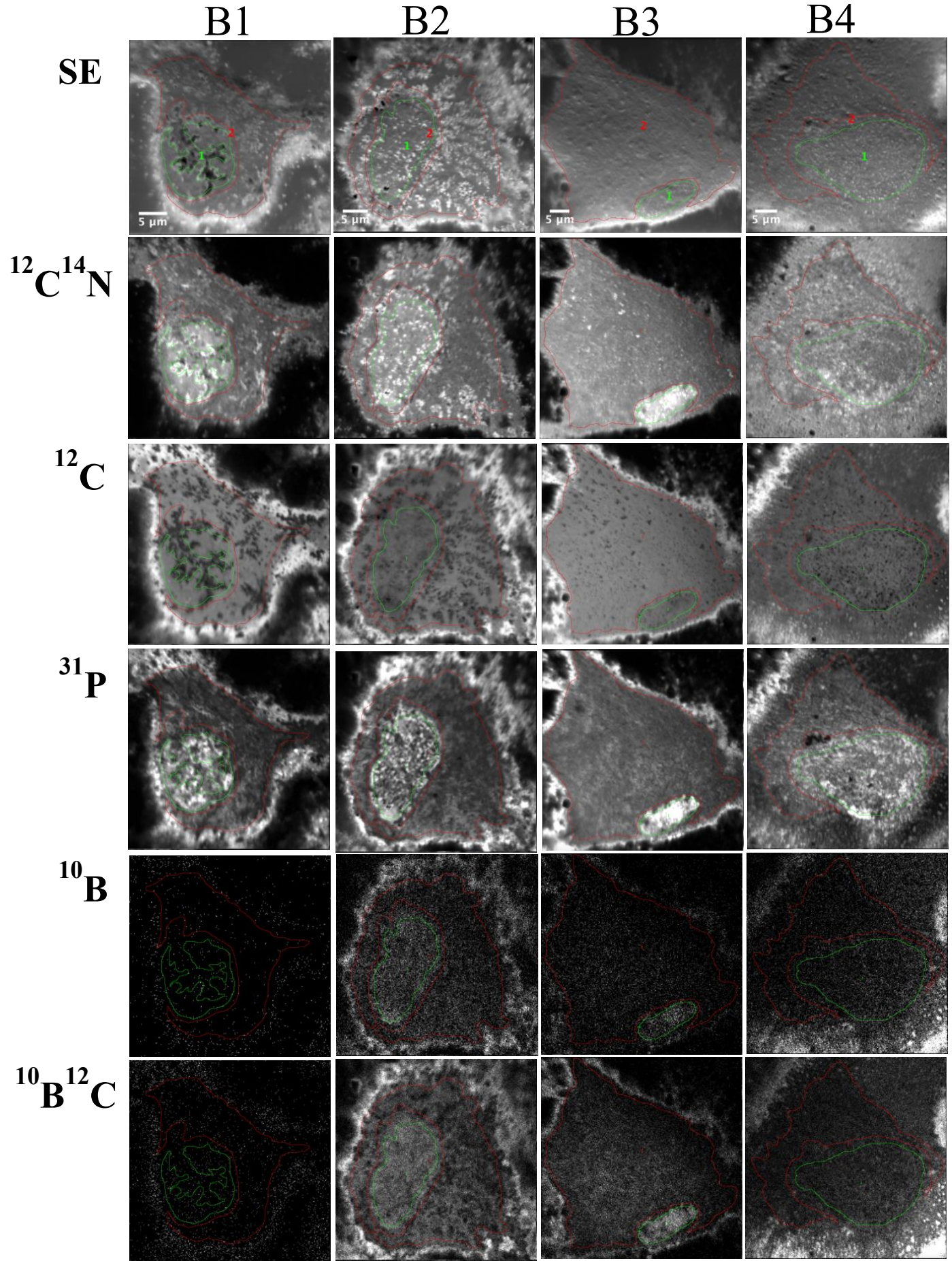

Figure 3: NanoSIMS images showing the four treatments for the Brain Around Tumour (BAT) cells, 1-4. SE: secondary electron images showing the overall structure of the cell. NanoSIMS maps reveal the distribution of ${ }^{12} \mathrm{C}^{14} \mathrm{~N}^{-},{ }^{12} \mathrm{C}^{-},{ }^{31} \mathrm{P}^{-},{ }^{10} \mathrm{~B}^{-}$ and ${ }^{10} \mathrm{~B}^{12} \mathrm{C}^{-}$within the cell, the nucleus is outlined with a green line and the cytoplasm outlined with a red line.

\subsection{Quantification of BPA uptake}


Relative quantification of BPA uptake in cell nuclei and cytoplasm as a function of the treatment regime (1-4) is given by normalizing ${ }^{10} \mathrm{~B}^{-}$and ${ }^{10} \mathrm{~B}^{12} \mathrm{C}^{-}$signals to ${ }^{12} \mathrm{C}^{-} .{ }^{12} \mathrm{C}^{-}$was chosen as it has the highest measured intensity and is the most homogenously distributed measured ion across the cell. Normalising two ions acquired simultaneously accounts for different image sizes and minimises the effect of primary ion beam current variations, total sputter yield and ion transmission, between different ROIs and images acquired across different NanoSIMS sessions. The ${ }^{10} \mathrm{~B}^{-} /{ }^{12} \mathrm{C}^{-}$ratio in SIMS analysis has previously been shown to correlate linearly with the bulk B concentration in BPA-doped (0-800 ppm) mouse brain tissue as determined by ICP-MS. ${ }^{59}$ The normalised ${ }^{10} \mathrm{~B}^{-}$and ${ }^{10} \mathrm{~B}^{12} \mathrm{C}^{-}$secondary ion intensity values from nuclei and cytoplasm of each sample are presented separately in box plots showing the mean $\left({ }^{\prime}{ }^{\prime}\right)$, median, the interquartile range, and the maximum and minimum values (Figure 4 and Figure 5).

Physiological levels of total boron in human soft tissues range from 0.1-10 ppm. ${ }^{60}$ Figure 4 shows normalised intensities of ${ }^{10} \mathrm{~B}^{-}$and ${ }^{10} \mathrm{~B}^{12} \mathrm{C}^{-}$from the control samples $\mathrm{T} 1$ and $\mathrm{B} 1$. For both boron-related signals, the normalized levels in these control samples are within experimental uncertainty (one standard deviation) when comparing nuclei to cytoplasm or tumour to BAT samples and have very similar boron levels. The overall ${ }^{10} \mathrm{~B}^{-} /{ }^{11} \mathrm{~B}^{-}$ratio measured in these control samples (across both nucleus and cytoplasm) with the NanoSIMS is $0.25 \pm 0.05$ (Figure S2), is in agreement with the natural isotopic ratio (0.25). The normalised intensities of the control samples are very low compared to the BPA-treated samples (Figure 5) which is consistent with them not having been exposed to the ${ }^{10} \mathrm{~B}$-enriched BPA formulation. 
Figure 5 compares the ${ }^{10} \mathrm{~B}^{-} /{ }^{12} \mathrm{C}^{-}$and ${ }^{10} \mathrm{~B}^{12} \mathrm{C}^{-} /{ }^{12} \mathrm{C}^{-}$ratios between treatments $2-4$ for both tumour and BAT samples. The signals from ${ }^{10} \mathrm{~B}^{12} \mathrm{C}^{-}$are always higher than from ${ }^{10} \mathrm{~B}^{-}$as explained previously. For treatment 2 and 3, both ratios indicate an increased level of BPA uptake in cell nuclei compared to cytoplasm. For samples $\mathrm{T} 2$ and $\mathrm{T} 3$ the mean ${ }^{10} \mathrm{~B}^{-} /{ }^{12} \mathrm{C}^{-}$ratio indicates nuclear:cytoplasm BPA distribution is 2.6 \pm 0.3 and for B2 and B3 samples the corresponding value is $2.1 \pm 0.1$. Using ${ }^{10} \mathrm{~B}^{12} \mathrm{C}^{-} /{ }^{12} \mathrm{C}^{-}$ratios the distribution values for Tumour (T2 \& T3) and BAT (B2 \& B3) are $2.5 \pm 0.2$ and 1.8 \pm 0.2 . The data clearly indicate a 2-fold excess of BPA in the nucleus compared to the cytoplasm under treatments 2 and 3. Treatment with BPA for $4 \mathrm{~h}$ results in an almost $40-70$ fold increase in the ${ }^{10} \mathrm{~B}^{-} /{ }^{12} \mathrm{C}^{-}$ratio in the nucleus and the cytoplasm compared to the control.

Adding tyrosine results in a significant $(p<0.05) \sim 50 \%$ decrease in boron uptake (measured by ${ }^{10} \mathrm{~B}^{-12} \mathrm{C}^{-}$ratio) in tumour samples (T3) compared to BPA-alone (T2). In our BAT samples the tyrosine has no significant effect. This finding is in agreement with the data of Detta and Cruickshank who examined brain tumour tissue harvested from human patients ${ }^{30}$, similar to the material presented in this study, and contrary to studies on other cell types. The data presented in this present study is also consistent with the conclusion of Grunewald et al (2017) that that the beneficial effect of preloading with tyrosine is not always observed. It is important from a therapeutic perspective to note that our data suggests that the intracellular distribution is not affected by tyrosine pre-treatment.

As expected, treatment 4 (efflux) greatly lowers the relative BPA levels in both cell types. In tumour samples (T4) the ${ }^{10} \mathrm{~B}^{-} /{ }^{12} \mathrm{C}^{-}$ratios in nucleus and cytoplasm are reduced almost an order of magnitude compared to (T2). In BAT samples (B2 and B4) the reduction is a factor 3-4. However, the ${ }^{10} \mathrm{~B}^{-} /{ }^{12} \mathrm{C}^{-}$and ${ }^{10} \mathrm{~B}^{12} \mathrm{C}^{-} /{ }^{12} \mathrm{C}^{-}$ratios following the efflux treatment for $4 \mathrm{~h}$ have 
not returned to the baseline levels and are approximately an order of magnitude greater than in the control samples (Figure 4). This indicates that the efflux process is slower than the BPA uptake. Pharmacokinetic profiles are key parameters in determining the optimum radiotherapy timepoint and dosage - ideally the boron agent should be cleared from healthy tissues and blood but retained in neoplastic cells at the time of irradiation.

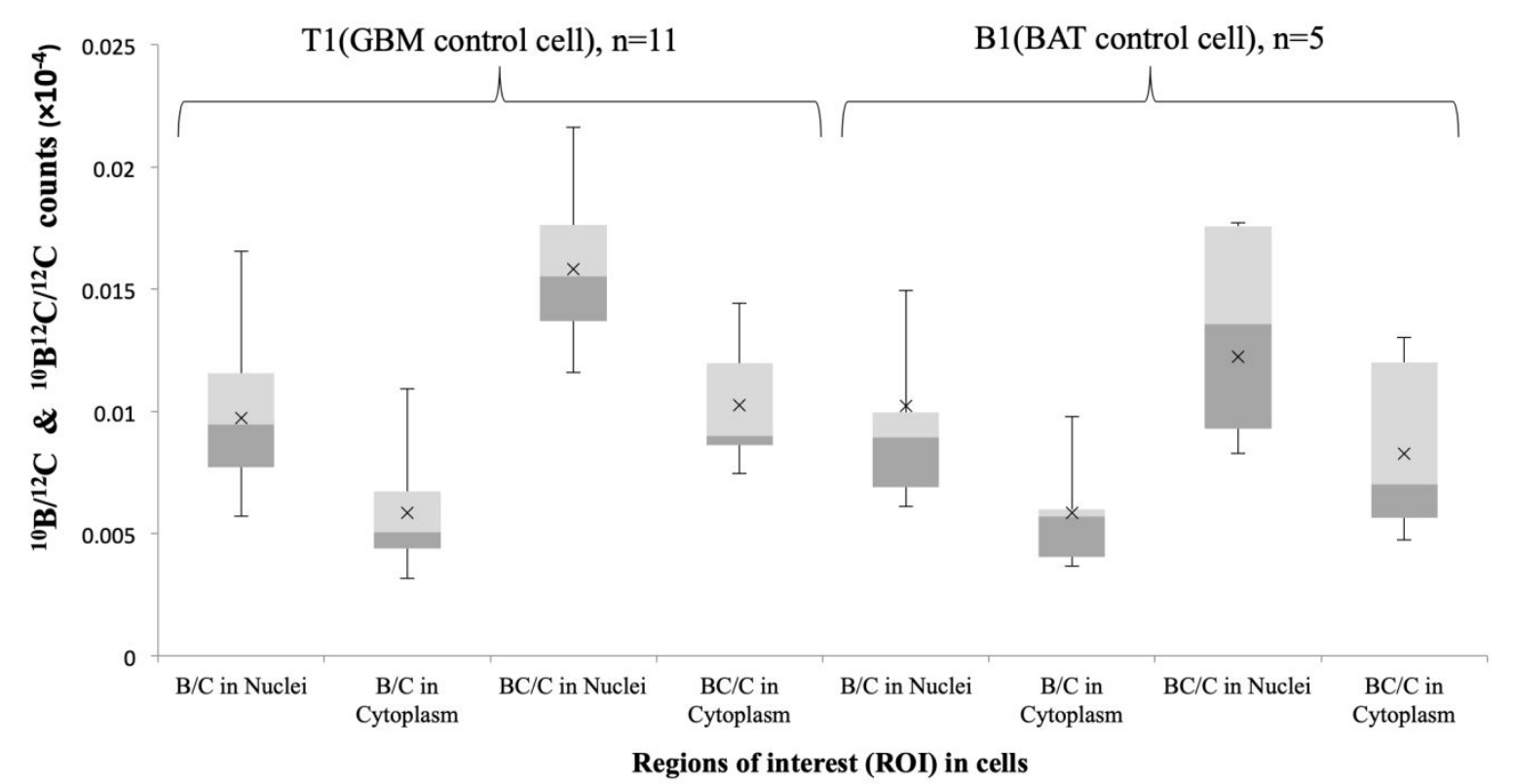

Figure 4: Comparison between the GBM and BAT-cell culture control samples treated with BPA (treatment 1) in terms of ${ }^{10} \mathrm{~B} /{ }^{12} \mathrm{C}$ and ${ }^{10} \mathrm{~B}^{12} \mathrm{C} /{ }^{12} \mathrm{C}$ ratios in the nuclei and cytoplasm regions measured by NanoSIMS. The ${ }^{10} \mathrm{~B}^{12} \mathrm{C} /{ }^{12} \mathrm{C}$ ratios in both cell compartments were higher than ${ }^{10} \mathrm{~B} /{ }^{12} \mathrm{C}$ ratios but the normalized levels for both ion ratios are within experimental error when comparing nuclei to cytoplasm or tumour to BAT samples. $n=$ number of cells analysed for each sample. 


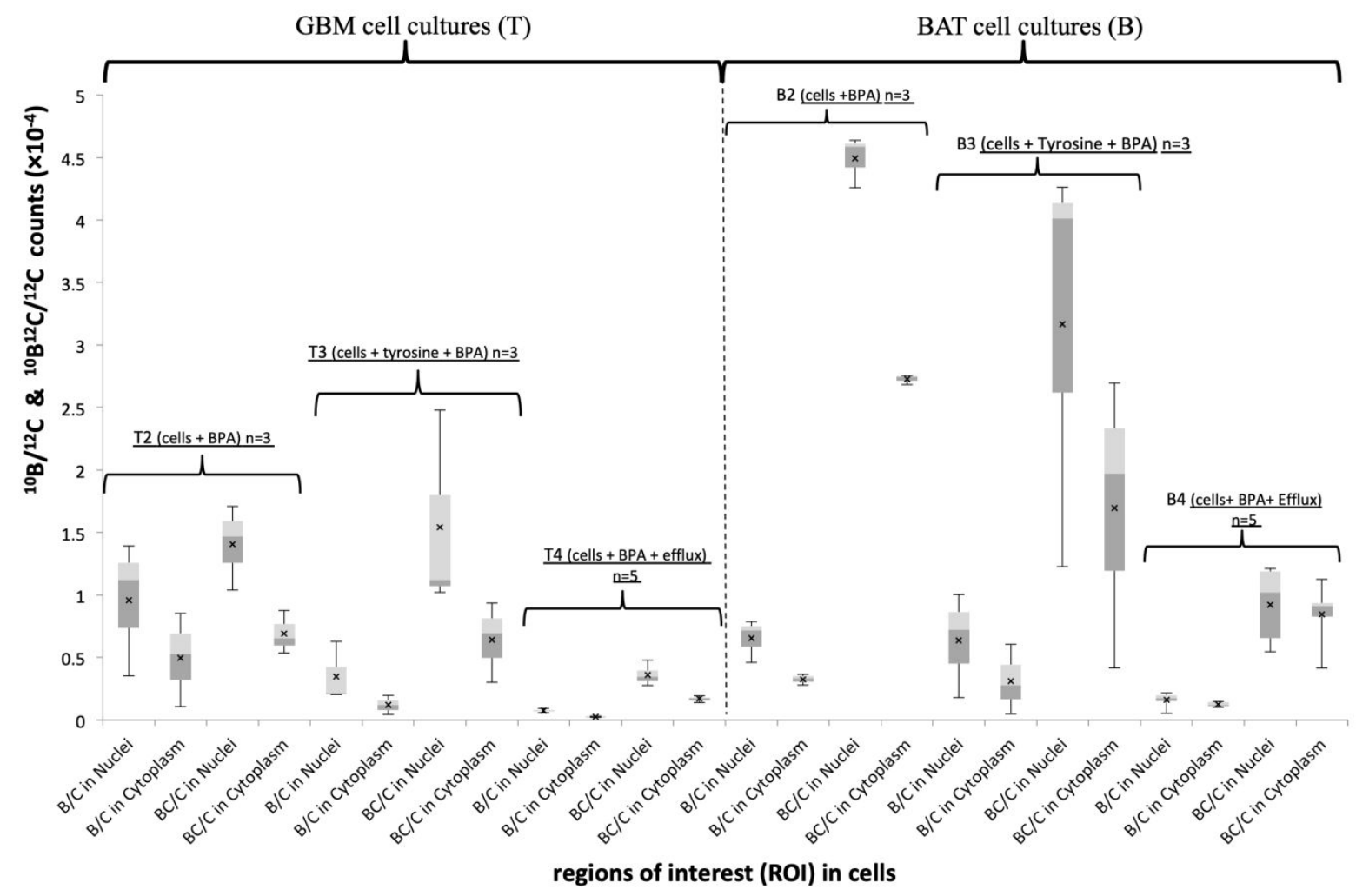

Figure 5: Comparison between the GBM and BAT-cell culture samples treated with BPA (treatments 2-4) in terms of ${ }^{10} \mathrm{~B} /{ }^{12} \mathrm{C}$ and ${ }^{10} \mathrm{~B}^{12} \mathrm{C} /{ }^{12} \mathrm{C}$ ratios in the nuclei and cytoplasm regions measured by NanoSIMS. The ${ }^{10} \mathrm{~B} /{ }^{12} \mathrm{C}$ and ${ }^{10} \mathrm{~B}^{12} \mathrm{C} /{ }^{12} \mathrm{C}$ ratios in nuclei areas were significantly higher than cytoplasmic areas in all samples. The ${ }^{10} \mathrm{~B}^{12} \mathrm{C} /{ }^{12} \mathrm{C}$ ratios in both cell compartments were usually higher than ${ }^{10} \mathrm{~B} /{ }^{12} \mathrm{C}$ ratios. $\mathrm{n}=$ number of cells analysed for each sample.

Absolute subcellular concentrations of ${ }^{10} \mathrm{~B}$ can be determined from the ${ }^{10} \mathrm{~B}^{-} /{ }^{12} \mathrm{C}^{-}$ion ratios and the relative sensitivity for $\mathrm{B}^{-}$in an appropriate matrix. Here we use the RSF value $\left(R S F_{\mathrm{B}}\right)$ obtained by Wilson et al. on a PMMA sample implanted with boron. ${ }^{55}$ Although not an exact match for the freeze-dried cell sample, we consider the polymer reference a close analogue to the biological sample. The dry-weight concentration $c_{B}(d r y)$ of ${ }^{10} \mathrm{~B}$ is given by $c_{B}(d r y)=$ $c_{C}(\mathrm{dry}) \cdot\left(I_{\mathrm{B}} / I_{\mathrm{C}}\right) \cdot R S F_{\mathrm{B}}$, where $c_{\mathrm{C}}(\mathrm{dry})$ is the dry weight carbon concentration (assumed $\left.100 \%\right)$, and $I_{B} / I_{C}$ is the ionic intensity ratio ${ }^{10} \mathrm{~B}^{-} /{ }^{12} \mathrm{C}^{-}$. From the dry-weight concentration the wetweight concentration $c_{B}$ can be determined assuming the water-content of live cells (85\%) and average cell density $\left(1 \mathrm{~g} / \mathrm{cm}^{3}\right)$. Using this approach we estimate the equivalent wet- 
weight concentrations of ${ }^{10} \mathrm{~B}$ in our measured regions of interest (Table 1 ), noting the therapeutic threshold of $\sim 15-30 \mu \mathrm{g} / \mathrm{g}$.

\begin{tabular}{|l|l|l|}
\hline \multirow{2}{*}{ Sample } & \multicolumn{2}{|l|}{$\begin{array}{l}{ }^{10} \mathrm{~B} \mu \mathrm{g} / \mathrm{g} \text { (wet wt.) } \\
\text { (Mean } \pm \text { SD) }\end{array}$} \\
\cline { 2 - 3 } & Nucleus & Cytoplasm \\
\hline $\begin{array}{l}\text { T1 ( } \mathrm{n}=11) \\
\text { Tumour control }\end{array}$ & $2.4 \pm 0.9$ & $1.4 \pm 0.5$ \\
\hline $\begin{array}{l}\text { T2 ( } \mathrm{n}=3 \text { ) } \\
\text { Tumour BPA }\end{array}$ & $240 \pm 130$ & $120 \pm 93$ \\
\hline $\begin{array}{l}\text { T3 ( } n=3) \\
\text { Tumour Tyr + BPA }\end{array}$ & $86 \pm 61$ & $30 \pm 20$ \\
\hline $\begin{array}{l}\text { T4 ( } n=5) \\
\text { Tumour BPA + efflux }\end{array}$ & $19 \pm 3.7$ & $6.5 \pm 1.1$ \\
\hline & $2.5 \pm 1.4$ & $1.4 \pm 0.6$ \\
\hline $\begin{array}{l}\text { B1 ( } n=5) \\
\text { BAT control }\end{array}$ & $160 \pm 43$ & $79 \pm 10$ \\
\hline $\begin{array}{l}\text { B2 }(n=3) \\
\text { BAT BPA }\end{array}$ & $160 \pm 100$ & $77 \pm 69$ \\
\hline $\begin{array}{l}\text { B3 }(n=3) \\
\text { BAT Tyr }+ \text { BPA }\end{array}$ & $39 \pm 16$ & $31 \pm 5$ \\
\hline $\begin{array}{l}\text { B4 }(n=5) \\
\text { BAT BPA + efflux }\end{array}$ & & \\
\hline
\end{tabular}

Table 1. Estimated ${ }^{10} \mathrm{~B}$ concentrations in sub-cellular regions of interest measured in this study.

Since an important goal of BNCT is to kill neoplastic cells invading the healthy tissue around the tumour core, it is interesting to compare the estimated BPA levels in cells from tumour (T) and BAT (B) samples. In a quantitative study of human GBM tumour biopsies using ICPMS, Detta et al. ${ }^{30}$ observed similar BPA uptake profiles in bulk samples from both regions. The explanation offered for this was that the higher LAT-1 expression in the infiltrating BAT cells led to increased uptake on a cell-by-cell basis and compensated for the lower number of neoplastic cells in the BAT compared to the tumour core. Having measured relative boron levels in individual cells we find that considering experimental uncertainty and/or cell-to-cell variations, the mean ${ }^{10} \mathrm{~B}$ concentrations are not significantly different in samples 
$\mathrm{T} 2$ and B2 (Table 1). Additionally, the nuclear concentrations of ${ }^{10} \mathrm{~B}$ measured for sample $\mathrm{T} 2$ and B2 in this work ( $200 \mu \mathrm{g} / \mathrm{g}$ wet wt.) are very similar to those reported in literature on cell lines or in animal models using different primary ion beams and mass analysers. , $^{9,11,61-64}$ Cytoplasm ${ }^{10} \mathrm{~B}$ concentrations for $\mathrm{T} 2 / \mathrm{B} 2$ samples are approximately $50 \%$ of those measured in previous studies. This may be due to differences in cell type or cell cycle stage at the point of fixation. As mentioned above, with tyrosine pre-treatment the mean boron level is significantly reduced in $\mathrm{T} 3$ samples $(\mathrm{p}<0.05)$ but not in $\mathrm{B} 3$ samples. Interestingly, the ${ }^{10} \mathrm{~B}^{12} \mathrm{C}^{-}$ $/{ }^{12} \mathrm{C}^{-}$ratios are significantly higher in BAT cells (B2 and $\mathrm{B} 3$ ) than in tumour core cells under the corresponding treatment. We are currently unable to estimate absolute concentration levels from the ${ }^{10} \mathrm{~B}^{12} \mathrm{C}^{-} /{ }^{12} \mathrm{C}^{-}$ion ratios without a relative sensitivity factor for the ${ }^{10} \mathrm{~B}^{12} \mathrm{C}^{-}$ion. This requires further calibration work using a more closely-matched matrix standard.

\section{Conclusions}

NanoSIMS analysis has determined the distribution of therapeutic BPA levels (> $100 \mu \mathrm{g} / \mathrm{g}$ of ${ }^{10} \mathrm{~B}$ wet wt.) in cultures of primary human glioblastoma cells, whether derived from the tumour core or from the brain around the tumour, and confirms an increased drug concentration in cellular nuclei compared to the cytoplasm. This is an important finding that has implications for the efficacy of BNCT treatment considering the short range of radiant energy transfer from irradiated ${ }^{10} \mathrm{~B}$ atoms. Tyrosine was found to result in a significant decrease $(\sim 50 \%)$ in cellular BPA uptake in cells from the tumour core (but not from the brain around tumour), but did not change the distribution of boron intracellularly. Our results suggest that the BPA efflux process is slower than the uptake process and is not complete within $4 \mathrm{~h}$. Residual levels of ${ }^{10} \mathrm{~B}$ in neoplastic cells derived from BAT are above the lethal BNCT threshold following $4 \mathrm{~h}$ efflux treatment. Together these observations represent the 
first intracellular study of BPA uptake and L-tyrosine pre-treatment in human cells. Although the sample numbers are small in this proof-of-principle study, due to the low throughput of the NanoSIMS technique, such analyses demonstrate cellular heterogeneity which bulk techniques cannot address. Our single cell localisation and quantification clearly demonstrate the utility of this approach for BNCT research and drug distribution studies more generally.

\section{Conflicts of Interest}

There are no conflicts to declare.

\section{Acknowledgments}

These samples were associated with a CR-UK funded study of the pharmacokinetics of 10Boron Phenylalanine (BPA) in patients with high grade glioma to optimize uptake parameters for Boron Neutron Capture Therapy (BNCT), LREC no. 05/Q2704/61. We gratefully acknowledge Prof. Garth Cruickshank and Dr. Allah Detta for providing the samples used in this study and for scientific discussions related to BNCT. The NanoSIMS instrument was funded by UK Research Partnership Investment Funding (UKRPIF) Manchester RPIF Round 2. SA was funded by a studentship from the Saudi Ministry of Higher Education and King Saud University. GM wishes to thank the UK Department for Business, Energy and Industrial Strategy for funding under the Industrial Strategy Challenge Fund program. 


\section{References}

1 D. N. Louis, H. Ohgaki, O. D. Wiestler, W. K. Cavenee, P. C. Burger, A. Jouvet, B. W. Scheithauer and P. Kleihues, Acta Neuropathol., 2007, 114, 97109.

2 A. Sarkar and E. A. Chiocca, in Brain Tumors, eds. A. H. Kaye and E. R. Laws, Elsevier Ltd, 3rd edn., 2012, pp. 384-407.

3 P. C. Burger, P. J. Dubois, S. C. Schold, K. R. Smith, G. L. Odom, D. C. Crafts and F. Giangaspero, J. Neurosurg., 1983, 58, 159-169.

4 R. Stupp, M. E. Hegi, W. P. Mason, M. J. van den Bent, M. J. B. Taphoorn, R.

C. Janzer, S. K. Ludwin, A. Allgeier, B. Fisher, K. Belanger, P. Hau, A. A.

Brandes, J. Gijtenbeek, C. Marosi, C. J. Vecht, K. Mokhtari, P. Wesseling, S.

Villa, E. Eisenhauer, T. Gorlia, M. Weller, D. Lacombe, J. G. Cairncross and

R.-O. Mirimanoff, Lancet Oncol., 2009, 10, 459-466.

5 R. F. Barth, A. H. Soloway, J. H. Goodman, R. A. Gahbauer, N. Gupta, T. E. Blue, W. Yang and W. Tjarks, Neurosurgery, 1999, 44, 433-451.

6 R. Gahbauer, N. Gupta, T. Blue, J. Goodman, R. Barth, J. Grecula, A. H. Soloway, W. Sauerwein and A. Wambersie, in Fast Neutrons and High-LET Particles in Cancer Therapy, eds. R. Engenhart-Cablic and A. Wambersie, Springer, 1998, pp. 183-209.

7 R. F. Barth, P. Mi and W. Yang, Cancer Commun., 2018, 38, 1-15.

8 M. J. Luderer, P. De La Puente and A. K. Azab, Pharm. Res., 2015, 32, 28242836.

9 S. Chandra and D. R. Lorey II, Int. J. Mass Spectrom., 2007, 260, 90-101.

10 A. C. Oyedepo, S. L. Brooke, P. J. Heard, J. C. C. Day, G. C. Allen and H. Patel, J. Microsc., 2004, 213, 39-45.

11 S. Chandra, T. Ahmad, R. F. Barth and G. W. Kabalka, J. Microsc., 2014, 254, 
$146-156$.

12 H. R. Snyder, A. J. Reedy and W. J. Lennarz, 1958, 835-838.

13 J. A. Coderre, J. D. Glass, R. G. Fairchild, P. L. Micca, I. Fand and D. D. Joel, Am. Assoc. Cancer Res., 1990, 50, 138-141.

14 S. Sjoberg, J. Carlsson, H. Ghaneolhosseini, L. Gedda, T. Hartman, J. Malmquist, C. Naeslund, P. Olsson and W. Tjarks, J. Neurooncol., 1997, 33, $41-52$.

15 A. Wittig, W. A. Sauerwein and J. A. Coderre, Radiat. Res., 2000, 153, 173180.

16 F. Verrey, Pflugers Arch. Eur. J. Physiol., 2003, 445, 529-533.

17 C. A. Wagner, F. Lang and S. Broer, Am J Physiol Cell Physiol, 2001, 281, C1077-C1093.

18 Y. Liu and Q. He, in Neurotoxicity of Nanomaterials and Nanomedicine, eds. X. Jiang and H. Gao, Elsevier Inc., 2017, pp. 33-57.

19 G. S. Cruickshank, D. Ngoga, A. Detta, S. Green, N. D. James, C. Wojnecki, J. Doran, J. Hardie, M. Chester, N. Graham, Z. Ghani, G. Halbert, M. Elliot, S. Ford, R. Braithwaite, T. M. T. Sheehan, J. Vickerman, N. Lockyer, H.

Steinfeldt, G. Croswell, A. Chopra, R. Sugar and A. Boddy, Appl. Radiat. Isot., 2009, 67, S31-S33.

20 H. Nawashiro, N. Otani, N. Shinomiya, S. Fukui, H. Ooigawa, K. Shima, H. Matsuo, Y. Kanai and H. Endou, Int. J. Cancer, 2006, 119, 484-492.

21 S. Asano, M. Kameyama, A. Oura, A. Morisato, H. Sakai, Y. Tabuchi, A. Chairoungdua, H. Endou and Y. Kanai, Biol. Pharm. Bull., 2007, 30, 415-422.

22 K. Ishiwata, Ann. Nucl. Med., 2019, 33, 223-236.

23 J. R. Jara, J. H. Martinez-Liarte, F. Solano and R. Peñafiel, J. Cell Sci., 1990, $97,479-485$. 
24 G. C. Gazzola, V. Dall'Asta and G. G. Guidotti, J. Biol. Chem., 1980, 255, 929936.

25 T. Lahoutte, V. Caveliers, S. M. R. Camargo, R. Franca, T. Ramadan, E. Veljkovic, J. Mertens, A. Bossuyt and F. Verrey, J. Nucl. Med., 2004, 45, $1591-1596$.

26 M. Papaspyrou, L. E. Feinendegen and H.-W. Muller-Gartner, Cancer Res., 1994, 54, 6311-6315.

27 B. Wingelhofer, K. Kreis, S. Mairinger, V. Muchitsch, J. Stanek, T. Wanek, O. Langer and C. Kuntner, Appl. Radiat. Isot., 2016, 118, 67-72.

28 S. Capuani, T. Gili, M. Bozzali, S. Russo, P. Porcari, C. Cametti, E. D’Amore, M. Colasanti, G. Venturini, B. Maraviglia, G. Lazzarino and F. S. Pastore, Int. J. Radiat. Oncol. Biol. Phys., 2008, 72, 562-567.

29 S. Capuani, T. Gili, M. Bozzali, S. Russo, P. Porcari, C. Cametti, M. Muolo, E. D’Amore, B. Maraviglia, G. Lazzarino and F. S. Pastore, Appl. Radiat. Isot., 2009, 67, S34-S36.

30 A. Detta and G. S. Cruickshank, Cancer Res., 2009, 69, 2126-2132.

31 C. Grunewald, M. Sauberer, T. Filip, T. Wanek, J. Stanek, S. Mairinger, S. Rollet, P. Kudejova, O. Langer, C. Schutz, M. Blaickner and C. Kuntner, Nucl. Med. Biol., 2017, 44, 83-89.

32 W. Yang, R. F. Bartha, T. Huo, G. W. Kabalkab, A. L. Shaikhb, S. A. Haiderc and S. Chandra, Appl Radiat Isot, 2014, 88, 69-73.

33 R. G. Fairchild and V. P. Bond, Int. J. Radiat. Oncol. Biol. Phys., 1985, 11, 831-840.

34 J. A. Coderrea and G. M. Morris, Radiat. Res., 1999, 151, 1-18.

35 A. Wittig, J. Michel, R. L. Moss, F. Stecher-Rasmussen, H. F. Arlinghaus, P. Bendel, P. L. Mauri, S. Altieri, R. Hilger, P. A. Salvadori, L. Menichetti, R. 
Zamenhof and W. A. G. Sauerwein, Crit. Rev. Oncol. Hematol., 2008, 68, 6690.

36 C. L. Schütz, C. Brochhausen, G. Hampel, D. Iffland, B. Kuczewski, G. Otto, T. Schmitz, C. Stieghorst and J. V. Kratz, Anal. Bioanal. Chem., 2012, 404, 1887-1895.

37 F. Basilico, W. Sauerwein, F. Pozzi, A. Wattig, R. Moss and P. L. Mauri, J. Mass Spectrom, 2005, 40, 1546-1549.

38 T. Kobayashi and K. Kanda, Radiat. Res., 1982, 91, 77-94.

39 D. Gabel, S. Foster and R. G. Fairchiled, Radiat. Res., 1987, 111, 14-25.

40 S. Chandra, Appl. Surf. Sci., 2003, 203-204, 679-683.

41 A. Portu, I. Postuma, M. A. Gadan, G. Saint Martin, M. S. Olivera, S. Altieri, N. Protti and S. Bortolussi, Appl. Radiat. Isot., 2015, 106, 171-175.

42 M. Dahlstrom, J. Capala, P. Lindstrom, A. Wasteson and A. Lindstrom, J. Neurooncol., 2004, 68, 199-205.

43 D. R. Smith, S. Chandra, R. F. Barth, W. Yang, D. D. Joel and J. A. Coderre, Cancer Res., 2001, 61, 8179-8187.

44 K. Yokoyama, S. Miyatake, Y. Kajimoto, S. Kawabata, A. Doi, T. Yoshida, M. Okabe, M. Kirihata, K. Ono and T. Kuroiwa, Radiat. Res., 2007, 167, 102-109.

45 R. D. Alkins, P. M. Brodersen, R. N. S. Sodhi and K. Hynynen, Neuro. Oncol., $2013,1-11$

46 P. Bendel, R. Margalit, N. Koudinova and Y. Salomon, Radiat. Res., 2005, $164,680-687$.

47 H. F. Arlinghaus, M. Fartmann, C. Kriegeskotte, S. Dambach, A. Wittig, W. Sauerwein and D. Lipinsky, Surf. Interface Anal., 2004, 36, 698-701.

48 J. R. Shapiro, B. M. Mehta, S. A. D. Ebrahim, A. C. Scheck, P. L. Moots and M. R. Fiola, in Boundaries between Promotion and Progression during 
Carcinogenesis, eds. O. Sudilovsky, H. C. Pitot and L. A. Liotta, Springer, Boston, 1991, pp. 243-262.

49 A. Detta, J. Harland, I. Hanif, S. M. Brown and G. Cruickshank, J. Gene Med., $2003,5,681-689$.

50 M. A. Farr-Jones, I. F. Parney and K. C. Petruk, J.Neurooncol., 1999, 43, 110.

51 R. I. Freshney, Culture of Animal Cells: A Manual of Basic Techniques, WileyLiss, New York, 3rd edn., 1994.

52 M. Carpano, M. Perona, C. Rodriguez, S. Nievas, M. Olivera, G. A. Santa Cruz, D. Brandizzi, R. Cabrini, M. Pisarev, G. J. Juvenal and M. A. Dagrosa, Int. J. Radiat. Oncol. Biol. Phys., 2015, 93, 344-352.

53 P. Hoppe, S. Cohen and A. Meibom, Geostand. Geoanalytical Res., 2013, 37, $111-154$

54 Brigham and Women's Hospital, Center for Nanolmaging, https://nano.bwh.harvard.edu/openmims, (accessed 4 July 2019).

55 R. G. Wilson, G. E. Lux and C. L. Kirschbaum, J. Appl. Phys., 1993, 73, 2524.

56 R. G. Wilson and S. W. Novak, J. Appl. Phys., 1991, 69, 466-474.

57 K. Fukuda, W. Fujiya, H. Hiyagon, Y. Makino, N. Sugiura, N. Takahata, T. Hirata and Y. Sano, Geochem. J., 2018, 52, 255-262.

58 M. Ito and S. Messenger, Meteorit. Planet. Sci., 2016, 51, 818-832.

59 I. Marchetti, L. Menichetti, C. Kusmic, L. A. de las Heras, P. Salvadori, R. Fuoco, F. Belloni, A. L'Abbate and M. Betti, Spectrochim. Acta Part B, 2009, 64, 911-920.

60 T. A. Devirian and S. L. Volpe, Crit. Rev. Food Sci. Nutr., 2003, 43, 219-231.

61 S. Chandra, W. Tjarks, D. R. Lorey and R. F. Barth, J. Microsc., 2008, 229, 92-103. 
62 D. R. Lorey, G. H. Morrison and S. Chandra, Anal. Chem., 2001, 73, 39473953.

63 S. Chandra, G. W. Kabalka, D. R. Lorey, D. R. Smith and J. A. Coderre, Clin. Cancer Res., 2002, 8, 2675-2683.

64 S. Chandra, D. R. Lorey II and D. R. Smith, Radiat. Res., 2002, 157, 700-710. 


\section{Supplementary Information}

a)

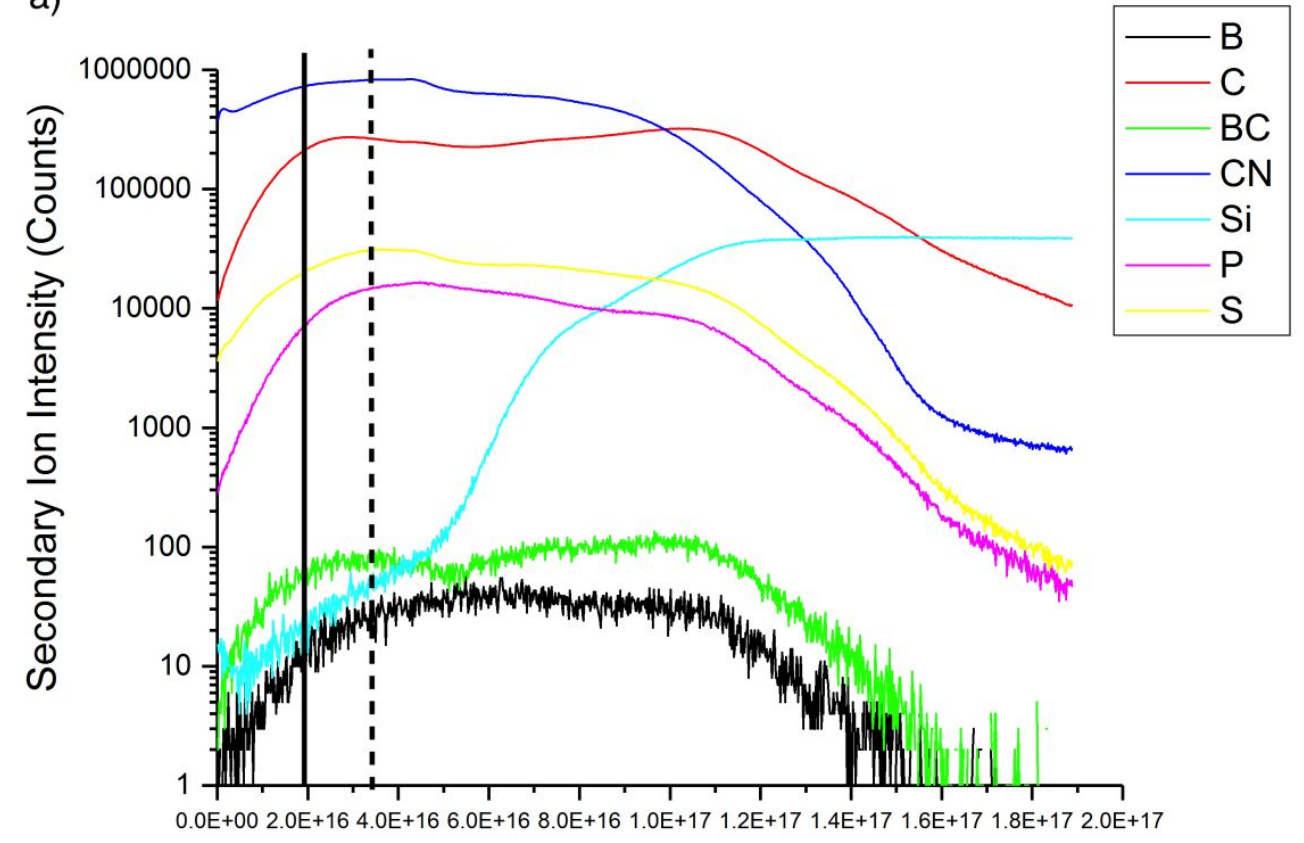

Cs+ ion dose (lons/cm2)

b)

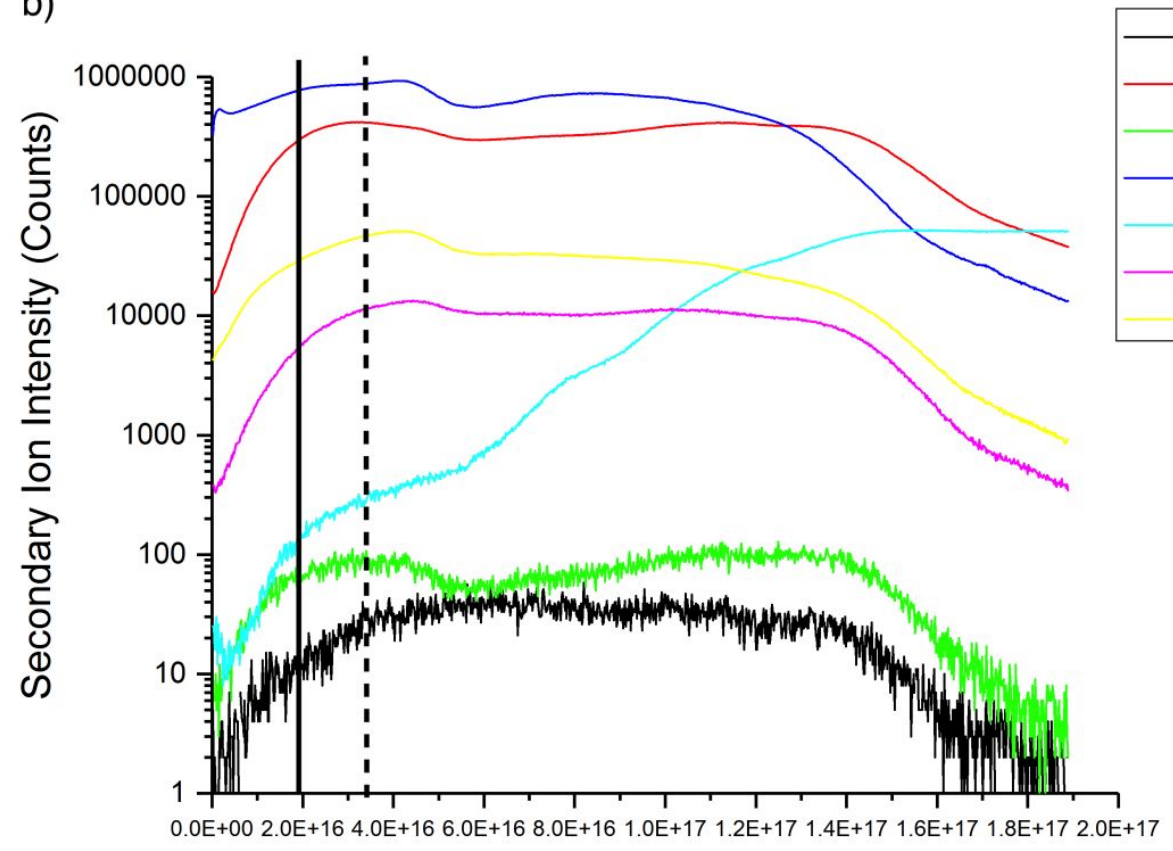

Cs+ ion dose (lons/cm2)

Figure S1: Depth profiles from a $40 \times 40 \mu \mathrm{m}^{2}$ image of a tumour cell showing the changes in intensity of negative secondary ions: ${ }^{10} \mathrm{~B},{ }^{12} \mathrm{C},{ }^{10} \mathrm{~B}^{12} \mathrm{C},{ }^{12} \mathrm{C}^{14} \mathrm{~N},{ }^{29} \mathrm{Si},{ }^{31} \mathrm{P}$ and ${ }^{32} \mathrm{~S}$ with $\mathrm{Cs}^{+}$ion beam dose. Intensities extracted from a) the nucleus and $\mathrm{b}$ ) the cytoplasm. Solid line indicates the implantation dose used $\left(1.9 \times 10^{16} \mathrm{Cs}^{+}\right.$ions $\left./ \mathrm{cm}^{2}\right)$ while the dotted line indicates the dose where analysis was stopped $\left(1.4 \times 10^{16} \mathrm{Cs}^{+}\right.$ions $\left./ \mathrm{cm}^{2}\right)$. 


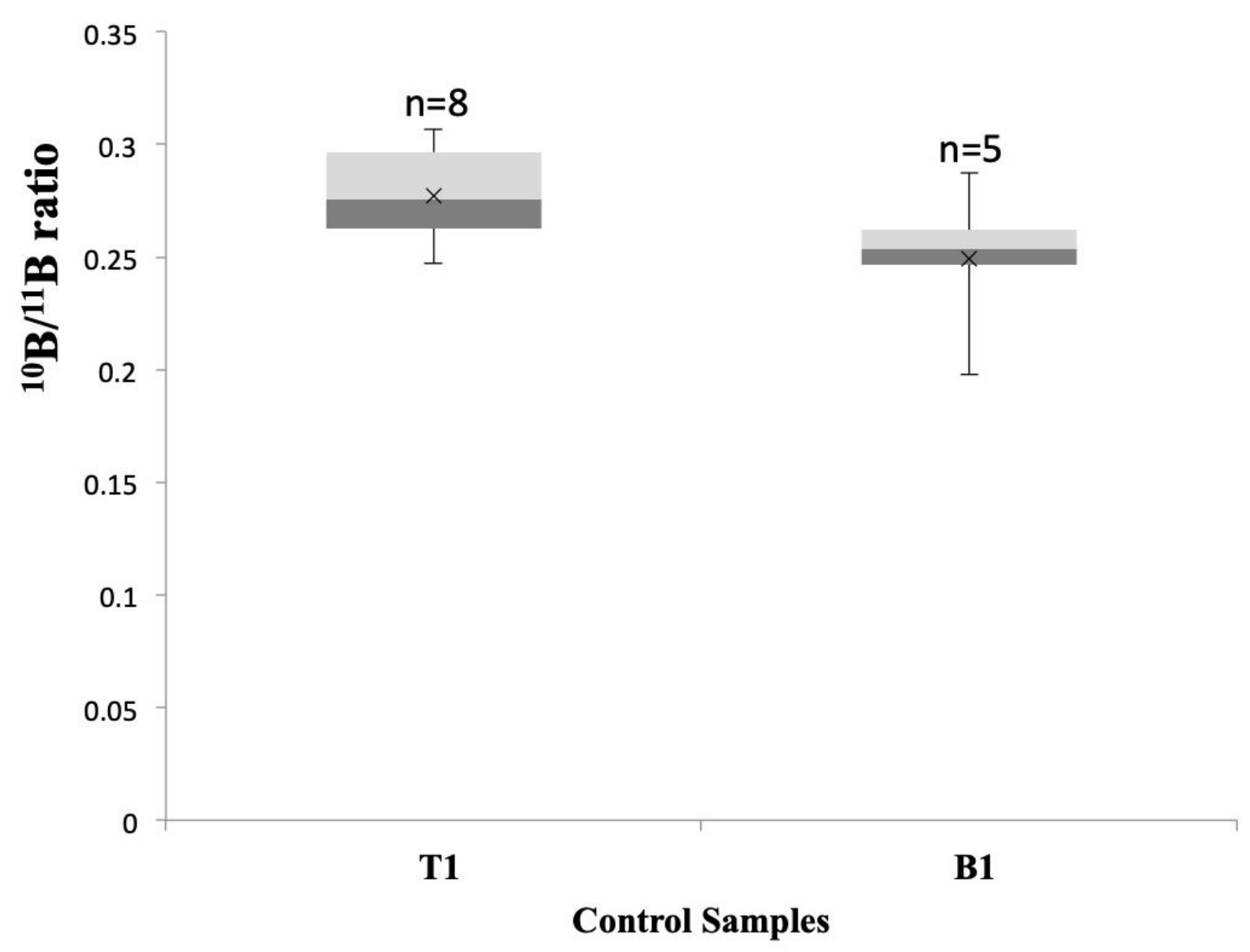

Figure $\mathrm{S} 2:{ }^{10} \mathrm{~B} /{ }^{11} \mathrm{~B}$ ratios from the control samples, $\mathrm{T} 1$ and $\mathrm{B} 1$, showing the natural isotope ratio $(0.25)$. The ratio has been calculated from the whole cell. Different cells were analysed for this measurement compared to the cells analysed in Figure 4. 


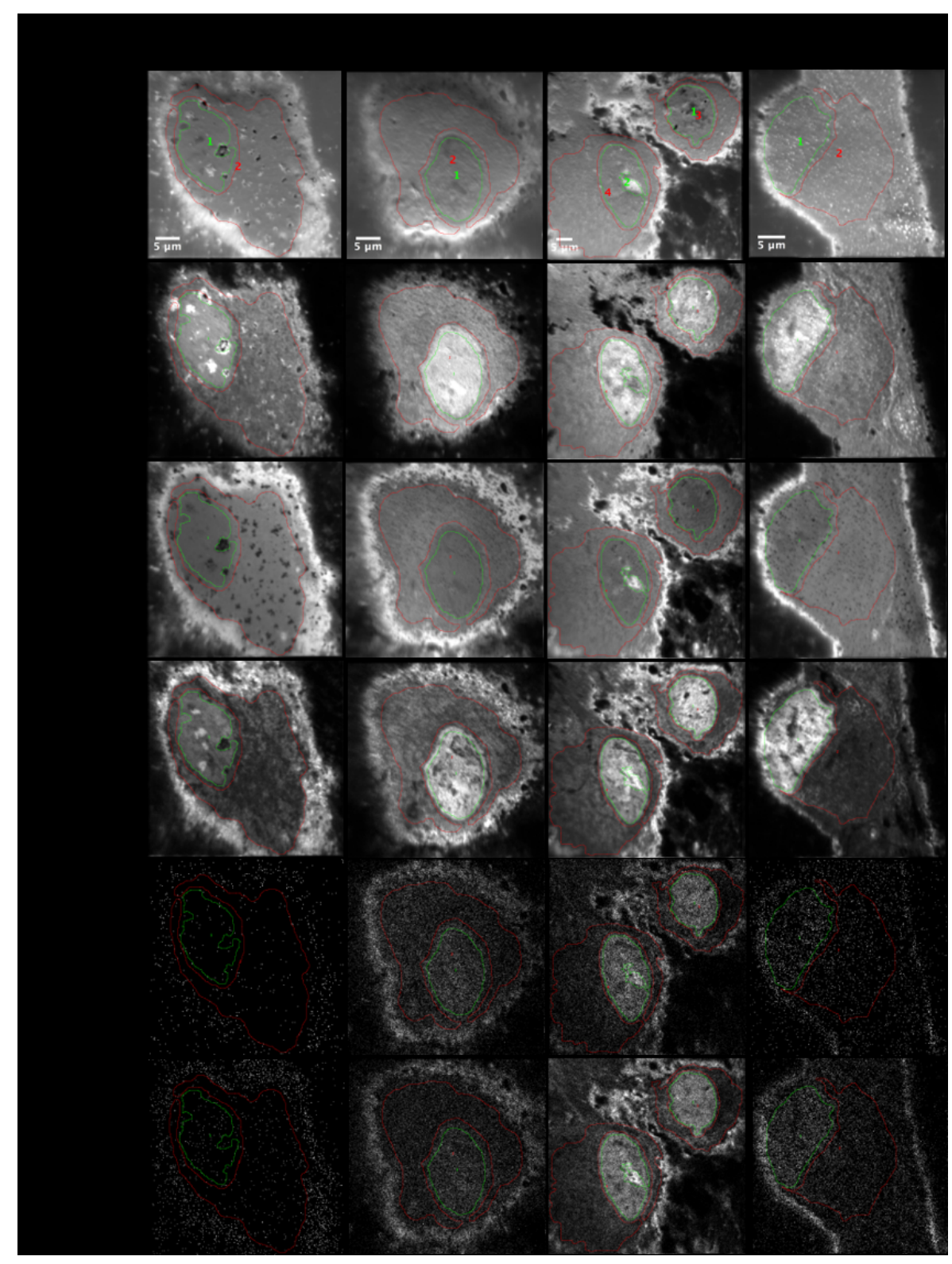

$143 \times 191 \mathrm{~mm}(150 \times 150 \mathrm{DPI})$ 


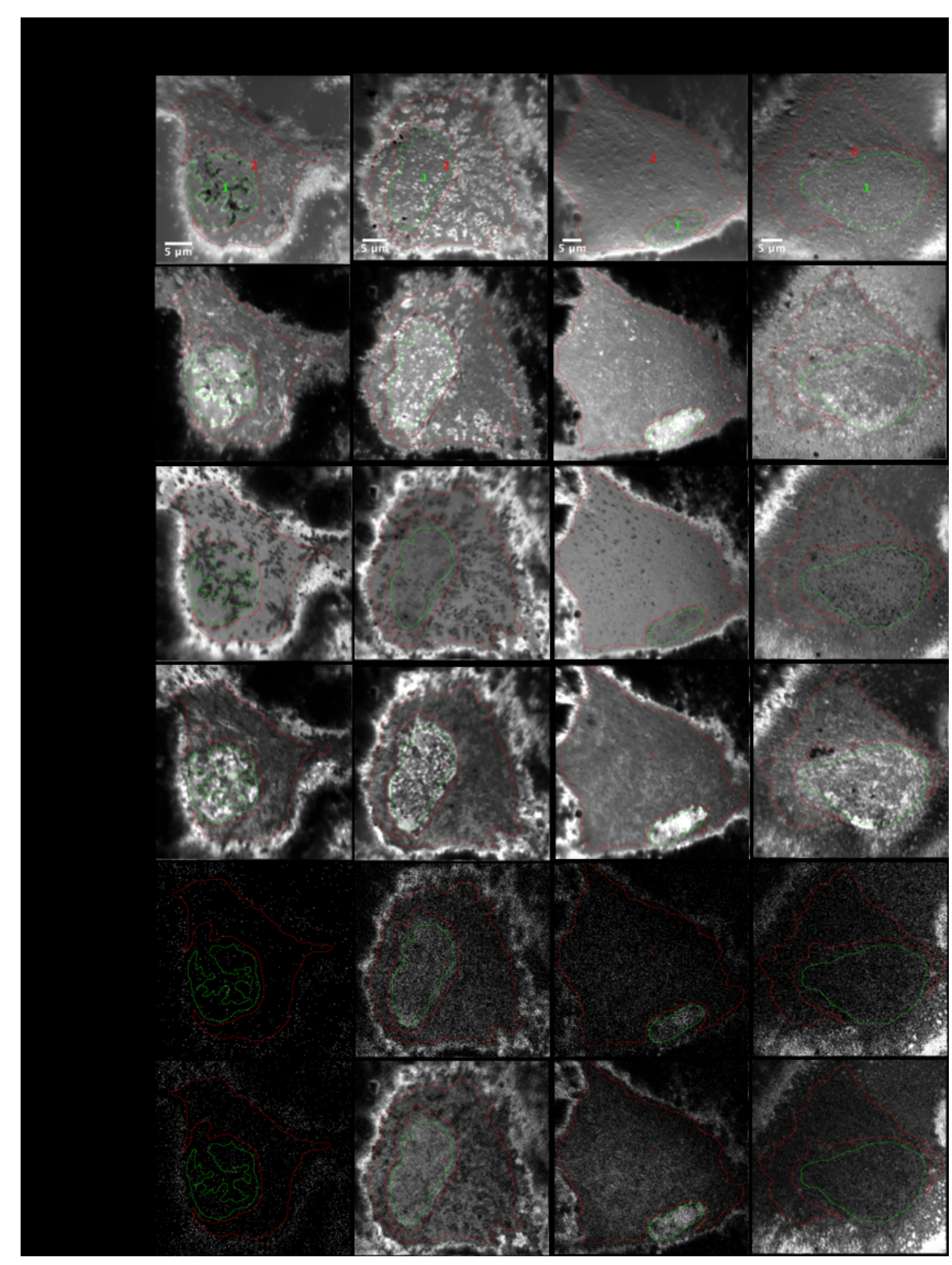

$143 \times 191 \mathrm{~mm}(150 \times 150 \mathrm{DPI})$ 


\section{Microdistribution and quantification of the boron neutron capture therapy drug BPA in} primary cell cultures of human glioblastoma tumour by NanoSIMS

Samar Aldossari ${ }^{1,2}$, Greg McMahon ${ }^{2,3,4}$, Nicholas P. Lockyer ${ }^{1,2}$, Katie L. Moore ${ }^{2,3}$

${ }^{1}$ School of Chemistry, University of Manchester, Oxford Rd, Manchester M13 9PL.

${ }^{2}$ Photon Science Institute, University of Manchester, Oxford Rd, Manchester M13 9PL

${ }^{3}$ School of Materials, University of Manchester, Oxford Rd, Manchester M13 9PL.

${ }^{4}$ Current address: National Physical Laboratory, National Centre of Excellence in Mass Spectrometry Imaging, Hampton Rd., Teddington, TW11 OLW

Nick.Lockyer@manchester.ac.uk

\section{Supplementary Information}

a)

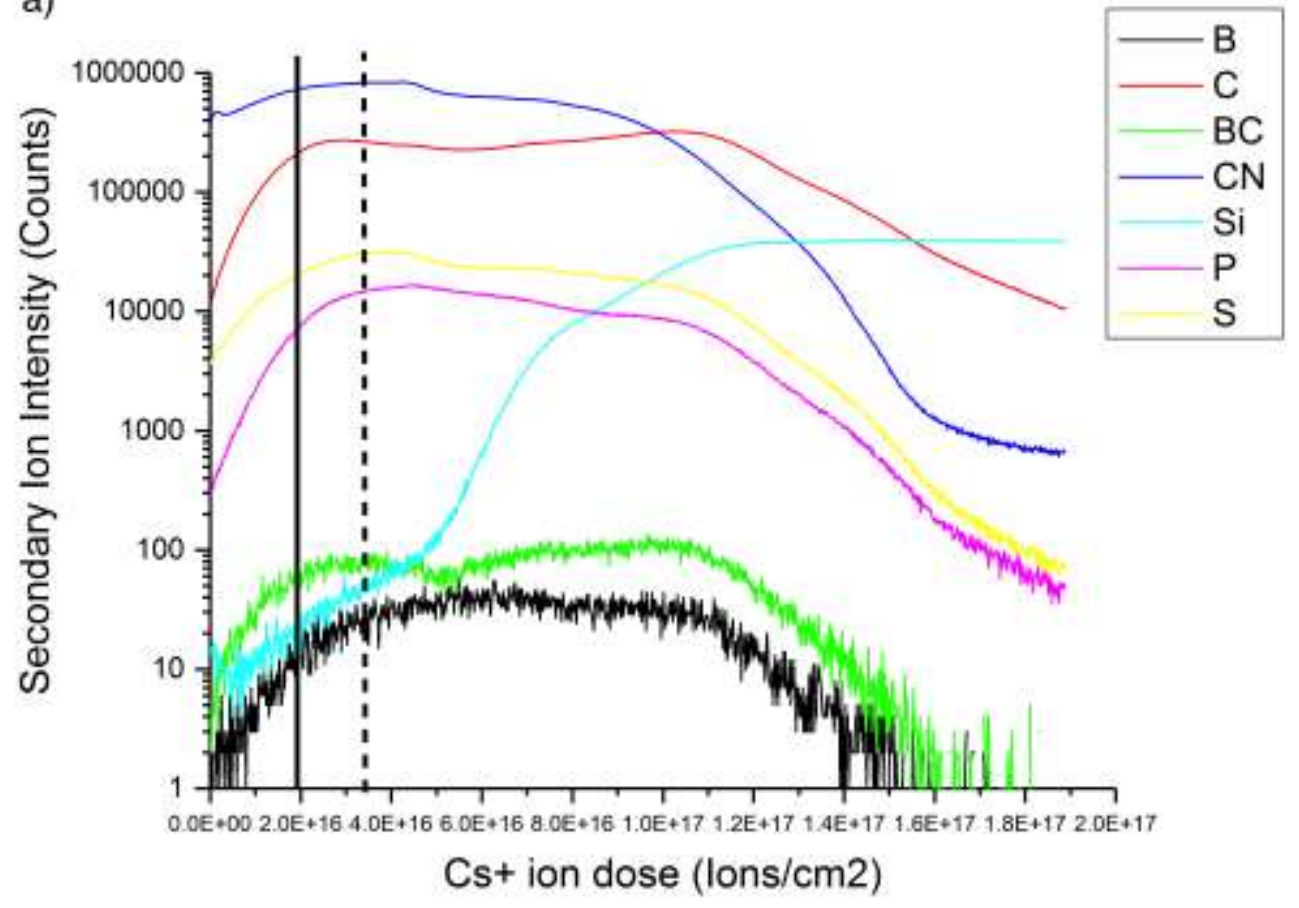




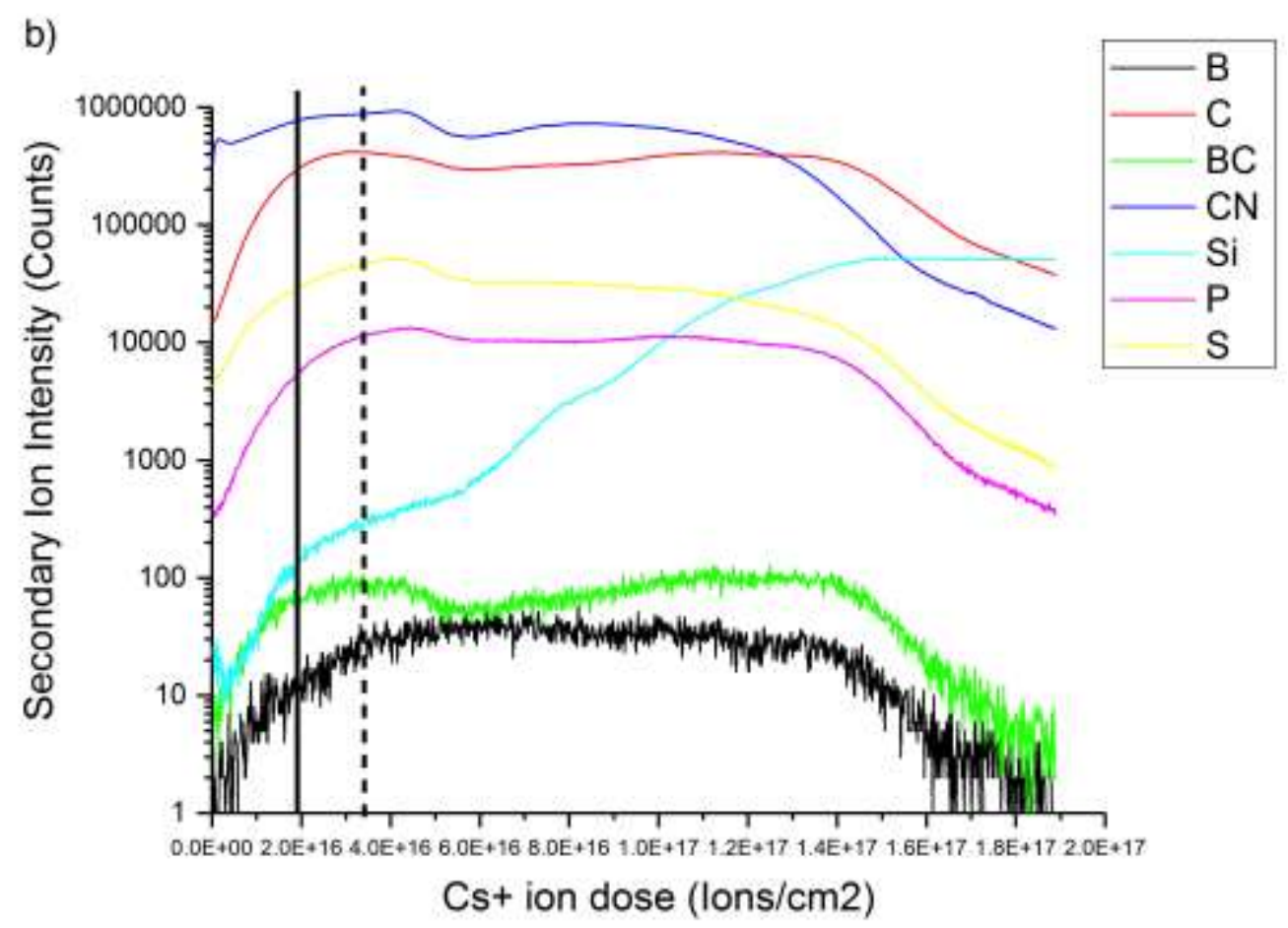

Figure S1: Depth profiles from a $40 \times 40 \mu \mathrm{m}^{2}$ image of a tumour cell showing the changes in intensity of negative secondary ions: ${ }^{10} \mathrm{~B},{ }^{12} \mathrm{C},{ }^{10} \mathrm{~B}^{12} \mathrm{C},{ }^{12} \mathrm{C}^{14} \mathrm{~N},{ }^{29} \mathrm{Si},{ }^{31} \mathrm{P}$ and ${ }^{32} \mathrm{~S}$ with $\mathrm{Cs}^{+}$ion beam dose. Intensities extracted from a) the nucleus and $\left.\mathrm{b}\right)$ the cytoplasm. Solid line indicates the implantation dose used $\left(1.9 \times 10^{16} \mathrm{Cs}^{+}\right.$ions $\left./ \mathrm{cm}^{2}\right)$ while the dotted line indicates the dose where analysis was stopped $\left(1.4 \times 10^{16} \mathrm{Cs}^{+}\right.$ions $\left./ \mathrm{cm}^{2}\right)$. 


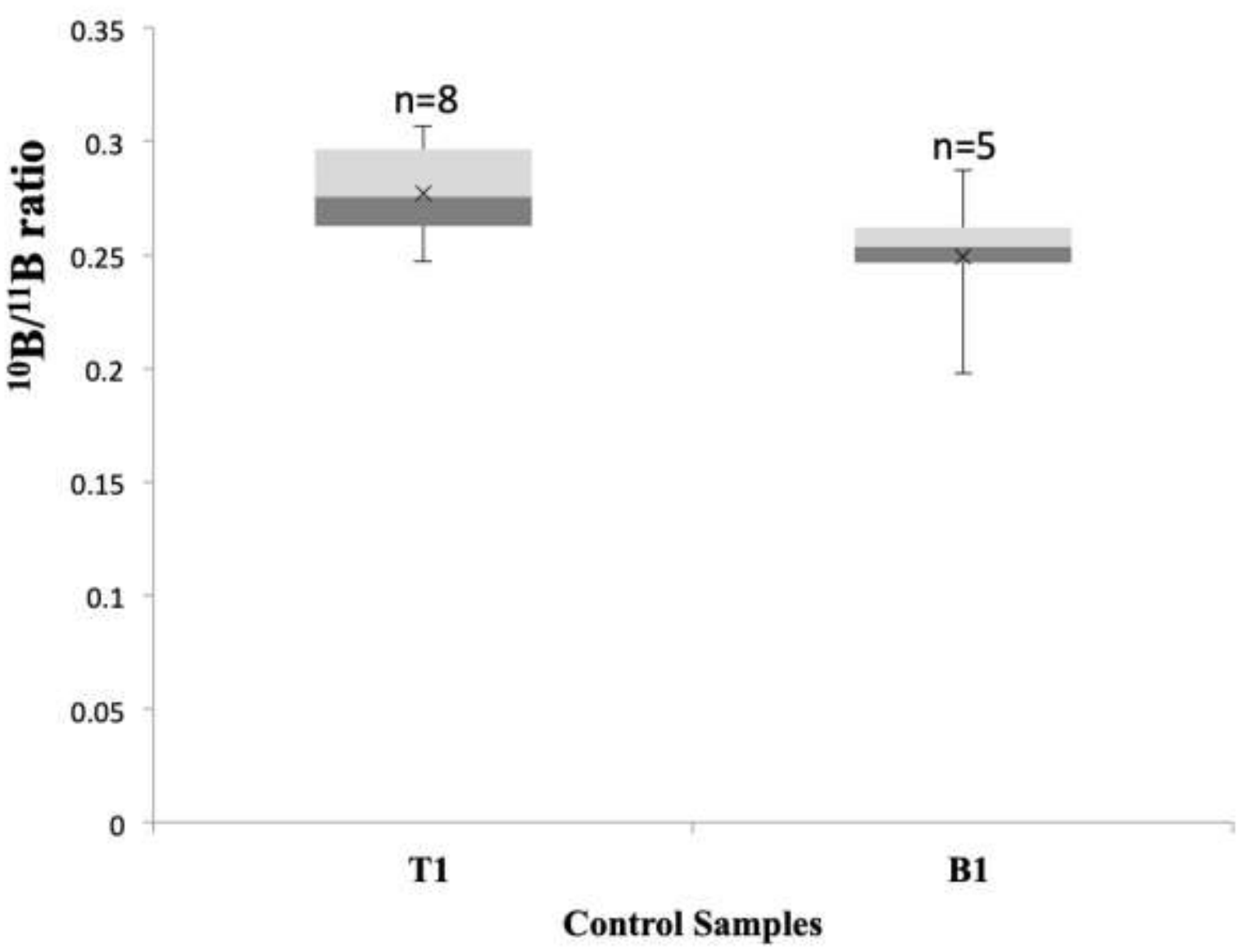

Figure $\mathrm{S} 2:{ }^{10} \mathrm{~B} /{ }^{11} \mathrm{~B}$ ratios from the control samples, $\mathrm{T} 1$ and $\mathrm{B} 1$, showing the natural isotope ratio $(0.25)$. The ratio has been calculated from the whole cell. Different cells were analysed for this measurement compared to the cells analysed in Error! Reference source not found. 